\title{
LA FRONTERA ENTRE LEÓN Y CÓRDOBA A MEDIADOS DEL SIGLO X: DESDE SANTARÉN A HUESCA
}

\author{
MANUEl CARRIEDO TEJEDO
}

\section{Resumen}

A través de las fuentes cronísticas más tempranas posibles, se analiza la línea fronteriza peninsular existente entre cristianos y musulmanes a mediados del siglo X (bajo los reinados de Ramiro II de León y de 'Abderrahmân III de Córdoba), tomando como punto de partida un curioso testimonio conservado en la obra de un prestigioso y fiable historiador cordobés del pleno siglo XI, Ibn Hayyân, quien, con motivo del acuerdo de paz alcanzado entre ambas comunidades en 941, traza una imaginaria línea divisoria ("desde Santarén a Huesca") que finalmente viene a ajustarse de forma muy exacta a la realidad territorial del momento.

\section{Palabras clave}

Frontera peninsular del siglo X. Reino de León. Ramiro II. Califato de Córdoba. 'Abdarrahmân III. Tratados de paz. Embajadas. Fuentes cronísticas musulmanas y cristianas.

\section{Summary}

Going through the earliest chronicles, I study the line of the peninsular frontier existing between Christians and Muslims in mid 10th century (under the reigns of Ramiro II of León and 'Abd ar-Rahmān III of Cordova), taking as a starting point a curious testimony preserved in the work of a prestigious, reliable Cordovan historian from the middle of the 11th century, Ibn Hayyān, who, on the occasion of the piece agreement reached between both communities in 941, draws an imaginary dividing line ("from Santarém to Huesca") which ultimately fits exactly into the territorial reality at the time.

\section{Key words}

The peninsular frontier in the 10th century. The Kingdom of León. Ramiro II. Caliphate of Cordova. 'Abd ar-Rahmān III. Piece agreements. Ambassadorial missions. Sources of Muslim and Christian chronicles.

\section{1.- INTRODUCCIÓN.}

Según el historiador cordobés Ibn Hayyân:

En du l-qa'da de este año (329 = 28 julio - 26 agosto de 941) quedó completa la paz con el tirano Ramiro (II de León) hijo de Ordoño, a quien Dios maldiga, concluyéndola (el califa 'Abdarrahmân III) an-Nâsir con la delegación enviada entonces por Ramiro a su capital, con las cláusulas que al califa plugo imponerse en solemne acto, como habia hecho el tirano Ramiro en su propia capital, habiéndose encargado de su delimi- 
tación y ratificación el judio Hasdây b. Ishâq que estaba en ésta. Todo concluyó excelentemente, poniéndose fin a la guerra entre las dos comunidades desde Santarén a Huesca, pues Ramiro asoció en el tratado al señor de Pamplona, García (I) hijo de Sancho, a Fernán González, conde de Castilla, a los Banû Gómez y Banû Ansúrez, y otros importantes condes leoneses ${ }^{1}$

Este párrafo, tan esclarecedor, frente a los monótonos registros de los cronistas cristianos ${ }^{2}$, encierra una frase curiosa que viene a ilustrar de forma muy esquemática el estado de las fronteras entre el reino de León y el califato de Córdoba a mediados del siglo X, pues, en efecto, el muy famoso y fiable Ibn Hayyân establece una línea divisoria imaginaria entrambos reinos que iba, dice, desde Santarén a Huesca. Ahora bien, ¿se trata en efecto de una simple línea imaginaria, o refleja, naturalmente a grandes rasgos, la realidad del estado fronterizo entre las dos comunidades a mediados del siglo X, justo en 941 ? La frase, sin duda muy sugerente, permite dar pie para acercarnos al estudio de una cuestión que, aunque no es desconocida, desde luego, sí se nos presenta por lo general (principalmente desde el territorio cristiano) de forma un tanto inconcreta, debido a la falta de testimonios contemporáneos densos de noticias más precisas al respecto ${ }^{3}$. Todo lo cual viene a complicarse por la poca estabilidad que las líneas fronterizas tuvieron en una época de guerra continuada; límites, siempre inseguros y con frecuencia cambiantes, que a menudo se establecen a través de accidentes geográficos significativos, cursos fluviales importantes ${ }^{4}$ y plazas fortificadas de cierta envergadura, donde cristianos y musulmanes mantenían sus respectivas tropas y los

\footnotetext{
${ }^{1}$ Vid. IBN HAYYÂN, Kitâb al-Muqtabis fi Ajbâr al-Andalus $V$, trad. M. J. VIGUERA y F. CORRIENTE, Crónica del califa 'Abdarrahmân III an-Nâsir entre los años 912 y 942 (al-Muqtabis V), Zaragoza 1981, p. 351 (= IBN HAYYÂN, al-Muqtabis V, en cuanto a la fuente; = VIGUERA, Crónica, en cuanto al estudio).

${ }^{2}$ En un pasaje de la Chronica Sampiri, de la misma significación política, se dice: "habuit pacem cum sarracenis"; ed. J. PÉREZ DE URBEL, Sampiro, su crónica y la monarquía leonesa en el siglo X, Madrid 1952, p. 340 (= Chronica Sampiri, en cuanto a la fuente; = PÉREZ DE URBEL, Sampiro, en cuanto al estudio).

${ }^{3}$ Si sólo dispusieramos de la Chronica Sampiri, la línea fronteriza más externa del reino de León, frente a los musulmanes, la darían las plazas de Coimbra y Osma, y en su recorrido, Salamanca, en el Tormes; ID., ibid., pp. 280, 323 y 327: "(Alfonso III) Coinbriam quoque ab inimicis obsesam defendit, suoque inperio subiugauit... exercitum mouit rex (Ramiro II), et obuiam illis exiuit in locum qui dicitur Oxoma... ad ripam Turmi ire disposuit (Ramiro II), et ciuitates desertas ibidem populauit: Salamantica... et alia plurima castella".

${ }^{4}$ Según el mal llamado Silense, Alfonso III derrotó a los musulmanes que, desde Toledo, "devastaban sus confines a lo largo del río Duero" (trad. M. GOMEZ-MORENO, Introducción a la Historia Silense, con versión castellana de la misma y de la Crónica de Sampiro, Madrid 1921, p. XCI) (= GÓMEZ-MORENO Historia Silense).
} 
depósitos de municiones suficientes como para guarnecer un determinado territorio de las ofensivas del enemigo ${ }^{5}$.

\section{2.- LAS FUENTES.}

Para trazar la línea fronteriza, nos hemos atenido a siete textos, cinco musulmanes y uno cristiano, todos ellos muy tempranos y de una fiabilidad fuera de duda, aunque son utilizados aquí, cuantitativamente hablando, de forma muy desigual.

En efecto, la fuente principal es, con mucha diferencia con respecto al resto, Ibn Hayyân, cuya obra es la espina dorsal del estudio y causa del mismo. Sin embargo, sería posible ilustrar no pocas de las plazas fronterizas musulmanas con una muy breve descripción contemporánea, sobre todo a partir de la obra de Ahmad ar-Râzî, hoy parcialmente conocida a través de la Crónica del Moro Rasis, pero también en la de otro geógrafo musulmán de mediados del siglo X, Ibn Hawqal. Por último, y sólo en lo que respecta a plazas fronterizas del reino leonés, traemos a cuento algunos pasajes del geográfo al-'Udrî y del Dikr bilâd alAndalus, sobre las campañas que contra ellas emprendió Almanzor en el último cuarto del siglo X. Y por lo que respecta a los textos cristianos, sólo la Crónica de Sampiro, que tiene aquí el interés de dar una versión de algunos pasajes desde el punto de vista cristiano. Ofrecemos a continuación un breve comentario sobre dichas fuentes:

1) IBN HAYYÂN.- Abu Marwân Hayyân b. Jalaf b. Hayyân, historiador, poeta y teólogo cordobés, hijo de un secretario de Almanzor, nació en Córdoba en 988, le tocó en suerte presenciar en su juventud la ruina del califato y murió en 1076. Su obra más importante es el famoso Kitâb alMuqtabis fi ajbâr al-Andalus ("Historia de la España musulmana"), que constaba de diez volúmenes, de los que sólo se conservan una pequeña parte: Lévi Provençal encontró hace unas décadas en la Mezquita Qarawiyyin de Fez el tomo II, correspondiente a los reinados de alHakam I (796-822), 'Abdarrahmân II (822-852) y parte del de Muhammad I (852-886); el tomo III, conocido de antiguo, trata sobre el reinado de Abdallâh (888-912); el tomo V, utilizado aquí, fue encontrado por Pedro Chalmeta hace varios años en la Biblioteca Real de Marruecos, y trata sobre una parte del reinado de 'Abdarrahmân III an-Nâsir li-Dîn

\footnotetext{
${ }^{5}$ Según Ibn Hayyân (al-Muqtabis, p. 151), en 924 era "Valtierra, última fortaleza musulmana, avanzada en territorio infiel, ordenando ('Abdarrahmân III) almacenar allí vituallas y repartir dinero a sus ocupantes para animarles a resistir en aquel punto débil".
} 
Allâh (912-961), concretamente los años comprendidos entre 912 y 942; $\mathrm{y}$, por último, el tomo VI, que estaba dedicado por entero al reinado de al-Hakam II (961-976), del que sólo se ha conservado un pequeño fragmento que comprende el período 971-975, también utilizado aquí por nosotros, aunque muy circunstancialmente ${ }^{6}$.

Entre las fuentes utilizadas por Ibn Hayyân (algunas de imposible identificación al referirse a ellas con la expresión "dice", si bien es muy posible que se esté refiriendo a los dos autores que se citan a continuación) se encuentran las muy importantes obras de dos de los Rasis, Ahmad b. Muhammad ar-Râzî y su hijo 'Îsà b. Ahmad ar-Râzî (por desgracia citados con frecuencia de forma indistinta como ar-Râzî); además de 'Arîb b. Sa'îd y de otros de menor importancia que cita Ibn Hayyân y que aquí ya no viene a cuento comentar de forma resumida:

-- AHMAD B. MUHAMMAD B. MÛSÀ AR-RÂZÎ AL-TA'RIJI.- Hijo de un mercader de origen árabe, Muhammad $b$. Mûsà, prosista, orador $y$ poeta, nacido en la localidad persa de Ray (de donde ar-Râzî), que se estableció en España a mediados del siglo IX. Fue autor de una obra titulada Libro de las Banderas, y en Córdoba nació ya su hijo Ahmad hacia el 887, autor, entre otras obras, de la Historia de los emires de alAndalus ("Ajbâr Mulûk al-Andalus"), cuyo relato alcanzaba, al menos, hasta el año 941, según se desprende del Muqtabis de Ibn Hayyân: Ahmad b. Muhammad ar-Râzî dice que Ramiro hijo de Ordoño regaló a anNâsir este corán... y que le trajo su embajador... en safar de este año $(330=26 \text { octubre }-23 \text { noviembre } 941)^{7}$; por desgracia sólo es conocida parcialmente a través de una traducción muy tardía, la llamada Crónica del Moro Rasis, de la que volveremos a hablar. Para Sánchez-Albornoz, esta Historia bastaría para incluirlo "en el número de los grandes historiadores españoles de la Edad Media, con san Isidoro, Rodrigo Ximénez de Rada y Alfonso X el Sabio" ${ }^{8}$. Según al-Faradi, murió el 1 de noviembre de 955: Ahmad b. Muhammad b. Mûsà ben Bashair b. Hammad b. Laqit ar-Râzî, natural de Córdoba. Fue literato, orador elocuente y poeta. Nació en al-Andalus... compuso gran número de obras pertenecien-

\footnotetext{
${ }^{6}$ Vid. C. SÁNCHEZ-ALBORNOZ, En torno a los orígenes del feudalismo. II. Fuentes de la historia hispanomusulmana del siglo VIII, Buenos Aires 1974, pp. 200-208 y 317-320 (= SÁNCHEZ-ALBORNOZ, Fuentes); IBN HAYYÂN, al-Muqtabis $V$ (trad. VIGUERA, Crónica); IBN HAYYÂN, al-Muqtabis, VI (ed. y trad. E. GARCÍA GOMEZ, Anales palatinos del califa de Córdoba al-Hakam II por 'Îsà ibn Ahmad al-Râzî, 360-364 $H .=971-975$ J.C., Madrid 1967) (= IBN HAYYÂN, Anales palatinos).

${ }^{7}$ ID., al-Muqtabis V, pp. 356-357.

${ }^{8}$ Vid. SÁNCHEZ-ALBORNOZ, Fuentes, pp. 95-96, 122-39 y 311-313.
} 
tes a la historia de al-Andalus. Murió un viernes a 12 noches pasadas de rayab del año $344^{9}$.

-- 'ÎSÀ B. AHMAD AR-RÂZÎ.- El tercero de los Rasis, hijo del anterior, es un hombre del pleno siglo X, muerto en el año 989, según registra el propio Ibn Hayyân. Escribió, entre otras obras, unos Anales de alAndalus, que dedicó al califa al-Hakam II, y de la que todavía se sirve el Muqtabis al trazar el reinado de este califa en su tomo VI, según sabemos por el fragmento hoy conocido ${ }^{10}$. No fue 'Îsà continuador de la obra paterna, pues coinciden, cronológica y textualmente hablando, el referir hechos concretos de la historia de al-Andalus, según se desprende del propio Muqtabis, aunque sí es seguro que 'Îsà aprovechó, como es natural, la obra de su padre Ahmad ${ }^{11}$ :

\section{AHMAD AR-RÂZî}

Ahmad b. Muhammad ar-Râzî, padre de 'Îsà, resume esta campaña en su Mujtasar, diciendo...

(an-Nâsir recibió) por el camino la buena nueva de la muerte de 'Amrus b. Muhammad, llamado at-Tawil, señor de Barbastro, ciudad importante de la Marca Superior, así como de sus fortalezas adyacentes que dan a Pallars en la frontera de Barcelona, capital franca, volviendo sus poblaciones a la obediencia.

\section{'ÎSÀ AR-RÂZî}

Dice 'Îsà b. Ahmad:...

(an-Nâsir) recibió la buena nueva de la muerte de 'Amrus b. Muhammad, señor de la ciudad de Barbastro, en la Marca Superior, y de que sus fortalezas adheridas, que dan a Pallars, en país franco, habían acordado someterse.

-- 'ARÎB B. SA'ÎD.- Historiador, médico y poeta cordobés, fue nombrado gobernador de la cora de Osuna por 'Abdarrahmân III en 943; ejerció luego diversos cargos palatinos con su hijo al-Hakam II; y alcanzó a vivir hasta el reinado de Hišâm II, cuyo ministro, el famoso Almanzor, le tuvo en gran estima; muriendo al fin hacia el año $980^{12}$. Su obra histórica sólo se ha conservado de forma muy parcial; no así su producción médica y su famoso Calendario de Córdoba, escrito en 961: Aquí comienza el Libro de los Tiempos (Kitâb al-Anwa'). Él está destinado para recordar las estaciones del año, el regreso periódico de los tiempos, las épocas de las plantaciones, los procedimientos agrícolas, las rectificaciones de las estaciones y la recogida de los frutos. Esta obra es de 'Arîb ben Sa'd,

\footnotetext{
${ }^{9}$ Vid. ANTONIO ARJONA CASTRO, Anales de Córdoba musulmana (711-1008), Córdoba 1982, p. 107 (= ARJONA, Anales).

${ }^{10}$ Vid. SÁNCHEZ-ALBORNOZ, Fuentes, pp. 95-96, 178-184 y 314-316.

${ }^{11}$ Vid., por ejemplo, los dos pasajes que siguen de IBN HAYYÂN, al-Muqtabis $V$, pp. 178-179, aunque hay otras coincidencias.

${ }^{12}$ Vid. SÁNCHEZ-ALBORNOZ, Fuentes, pp. 95-96, 172-177; etiam VIGUERA y CORRIENTE, Crónica, p. 382.
} 
juntamente con Rabi' ben Zayd (Recemundo de Elvira), el obispo, y fue compuesta para el califa (al-Hakam II) al-Mustansir ${ }^{13}$.

2) CRÓNICA DEL MORO RASIS.- Se conoce con este nombre a la traducción castellana anterior a 1344, de la versión portuguesa de un original árabe de Ahmad b. Muhammad ar-Râzî, traducido por un musulmán iletrado, llamado Muhammad, y realizada por un clérigo llamado Gil Pérez para el rey Dionis de Portugal (1279-1325), nieto de Alfonso X el Sabio. Tal y como hoy la conocemos, consta de dos partes, la segunda, una Historia General de España, y, la primera, una Descripción General de Al-Andalus que es la que aquí nos interesa, pues el autor da cabida sólo a las plazas (en nuestro caso las fronterizas) que se encontraban en poder de los musulmanes, pues non conto de las que los moros avian ya perdidas nin otras muchas que fincaron yermas. Para SánchezAlbornoz "constituye una pérdida irreparable la desaparición de las obras del segundo de los Rasis... el conjunto de la historiografía posterior no nos compensa de tal pérdida, ni tampoco la versión de una parte de la obra de ar-Râzî, llamada Crónica del Moro Rasis", y aunque continúa con que "la crónica romance está muy lejos de reemplazar al original árabe"14, coincide con Diego Catalán en que "Gil Pérez no mintió, o metió, en ella ni más ni menos que lo que leyeron Muhammad y sus auxiliares moros"15.

3) IBN HAWQAL.- Famoso geógrafo y explorador árabe que llegó al califato en el año 948, en pleno reinado de Abdarrahmân III, y en consecuencia fue testigo directo de la realidad del siglo X: "Entró en España a comienzos del año 337 (948), cuando reinaba Abû l-Mutarrif 'Abd alRahmân ibn Muhammad". Fue autor de una gran obra titulada Configuración del Mundo, dos de cuyos capítulos están dedicados a la Península y el Magreb ${ }^{16}$.

4) AHMAD IBN 'UMAR IBN ANAS AL-'UDRÎ AL-MARIYYI (10031085).- Geógrafo español del siglo XI, que recoge y ennumera las veinticinco primeras campañas emprendidas por Almanzor, extremadamente

\footnotetext{
${ }^{13}$ Vid. ARJONA, Anales, p. 126.

${ }^{14}$ Vid. SÁNCHEZ-ALBORNOZ, Fuentes, 95-96, pp. 139-158.

${ }^{15}$ Crónica del Moro Rasis, versión del Ajbâr Muluk al-Andalus de Ahmad ibn Muhammad ibn Mûsà ar-Râzî, 889-955, romanzada para el rey don Dionis de Portugal hacia 1300 por Mahomad, alarife, y Gil Pérez, clérigo de don Perianes Porçel; ed. pluritextual preparada por DIEGO CATALÁN y MARIA SOLEDAD DE ANDRÉS en el Seminario Menéndez Pidal, año 1974, Madrid 1975, p. XII (=Crónica del Moro Rasis, en cuanto a la fuente, = CATALÁN, Crónica, en cuanto al estudio).

${ }^{16}$ IBN HAWQAL, Configuración del Mundo, fragmentos alusivos al Magreb y España; trad. MARIA JOSÉ ROMANÍ SUAY, Valencia, 1971 (= IBN HAWQAL).
} 
resumidas, pero con la afortunada expresión de su cronología y los puntuales objetivos de cada una ${ }^{17}$. Contra la opinión de Seco de Lucena y Osvaldo Machado, cree Antonio Molina que al-'Udrî no utilizó, aquí al menos, la obra de Ibn Hayyân, aduciendo como prueba que el historiador cordobés sí conoció las dos algazúas de Almanzor contra Algeciras (recogidas luego por el Dikr bilâd al-Andalus), las cuales no registró al'Udrî ${ }^{18}$. Sin embargo, según Viguera, el geógrafo almeriense sí conoció la obra de 'Îsà ar-Râzî1'

5) DIKR BILÂD AL-ANDALUS.- En palabras de Molina, se trata de "un compendio histórico-geográfico de autor anónimo... redactado en el Magreb entre finales del siglo XIV y la caída de Granada", cuyo autor recoge y ennumera las cincuenta y seis campañas victoriosas emprendidas por Almanzor, aunque resumiendo en demasía y omitiendo las fechas en que tuvieron lugar. Sin embargo, para el referido autor, este texto anónimo resulta tan valioso como el de al-'Udrî, remarcándose dicha autoridad de forma muy notable, al citar expresamente al gran Ibn Hayyân, que en consecuencia es fuente del anónimo recopilador, aunque fuente indirecta, en opinión de Molina ${ }^{20}$.

6) CRÓNICA DE SAMPIRO.- Presbítero leonés nacido probablemente en El Bierzo hacia $960-970^{21}$. Trasladado a León hacia el año 990, procedente de las actuales tierras zamoranas del norte (aún hoy inscritas en la diócesis asturicense), donde tal vez profesaba en algún monasterio que abandonó como consecuencia de las insistentes campañas de Almanzor contra la línea del Duero medio, fue acogido muy pronto en el palacio de Vermudo II (982-999) ${ }^{22}$, donde ejerció el cargo de notario real, siendo

\footnotetext{
${ }^{17}$ Vid. SÁNCHEZ-ALBORNOZ, Fuentes, pp. 95-96, 320; etiam CATALÁN, Crónica, pp. LXI-LXIX; al'Udrî, trad. J. M. RUIZ ASENCIO, "Campañas de Almanzor contra el reino de León (981-986) ", Anuario de Estudios Medievales, V, 1968 (= al-'Udrî, en cuanto a la fuente; = RUIZ ASENCIO, Campañas, en cuanto al estudio).

${ }^{18}$ Vid. L. MOLINA, "Las campañas de Almanzor a la luz de un nuevo texto", al-Qantara, II, Madrid 1981, pp. 212-213 (= MOLINA, Las campañas).

${ }^{19}$ Vid. VIGUERA, Crónica, p. 448.

${ }^{20} \mathrm{Dikr}$ bilâd al-Andalus (así, en adelante, para la fuente), trad. MOLINA, Las campañas, pp. 210-263; etiam ID., Una descripción anónima de al-Andalus, II. Traducción y estudio, Madrid 1983, pp. 196-203.

${ }^{21}$ Sobre la vida y obra de este cronista puede consultarse el estudio ya citado de Pérez de Urbel (Sampiro, pp. 11-125) y A. QUINTANA PRIETO, El obispado de Astorga en el siglo XI, Astorga 1977, pp. 57-160.

${ }^{22}$ "Et ego pecator sub gladio et timendo mortis periculo euasi captiuidadem ad gens ismahelidarum... exiui de ciuitate Numantie... et exinde perueni in palatio domni mei serenissimi regis domni Ueremudi... et postea deueni in palatio filium eius domno meo, rex domno Adefonso" (ed. RUIZ ASENCIO, Colección documental del Archivo de la catedral de León -775-1230-, IV -1032-1109-, León 1990, doc. 1004, pp. 165-167, = RUIZ ASENCIO, Colección catedral de León, IV, doc. 1004, pp. 165-167). Según el geógrafo al-'Udrî (trad. ID., Campañas, pp. 56-64) las primeras campañas contra Zamora transcurrieron en 981, 984 y 986; y por el $D i k r$ bilâd al-Andalus (trad. MOLINA, Las campañas, pp. 231 y 251-252), sabemos que hubo otras dos, en 979 y 988. Sampiro aparece por primera vez en la corte leonesa el 25 de junio de 990 (ed. RUIZ ASENCIO, Colec-
} 
merecedor de la estima del monarca, que le premió con importantes mer$\operatorname{cedes}^{23}$. Durante la minoría de Alfonso V (999-1028) fue nombrado mayordomo del palacio, sin dejar sus funciones de notario, mereciendo de igual modo de este monarca diversos dones ${ }^{24}$. Retirado luego durante los días de Vermudo III (1028-1037) ${ }^{25}$, Sancho Garcés III de Pamplona le designó para ocupar la cátedra de Astorga en $1034^{26}$, y alcanzó a vivir, al menos, hasta 1042, reinando Fernando I (1038-1065) ${ }^{27}$. Su obra se ha conservado principalmente a través de dos textos del siglo XII, con desigual fortuna ${ }^{28}$, pues Pelayo de Oviedo la interpoló a su placer con pasajes de muy diversa significación, a veces intranscendentes, pero las más con la insana intención de engrandecer a su iglesia ${ }^{29}$; en tanto que la obra del notario leonés ha pasado intacta a la llamada Historia Silense, donde afortunadamente fue incluida a fin de reparar la desgraciada temprana pérdida de un cuaternión donde a buen seguro se narraban los reinados de los sucesores de Ordoño II (914-924), hasta Sancho I (956-966) ${ }^{30}$. La fuentes de Sampiro no son conocidas, a excepción de la Chronica Albeldensia, cuya huella puede seguirse en el reinado de Alfonso III ${ }^{31}$. Sin embargo, es probable que Sampiro dispusiera de algunos Anales, hoy desconocidos, donde se registraban también los cómputos regios, al me-

ción documental del archivo de la catedral de León -775-1230-, III -986-1031-, León 1987, doc. 541, pp. 4243) (= RUIZ ASENCIO, Colección catedral de León, III).

${ }^{23}$ Año 998: "Ego Ueremudus serenissimus princeps... tibi sacerdoti et famulanti nostro Sampiro... monasterium Sancti Migaeli uogabulo que uogatur Almazkara, territorio Bergido" (ed. ID. ibid., doc. 581, pp. 97-101).

${ }^{24}$ Año 1000: "Sampirus prebiter et notarius regis et maiorino" (ed. ID., ibid., doc. 594, pp. 115-117). Año 1001: "Sampirus presbiter qui et maiordomus regis" (ID., ibid., doc. 599, 122-124). Año 1023: "Ego Adefonsus serenissimus princeps tibi fidelem et notarius meus Sampirus presbiter... solare qui est en Uilla Taurelli" (ed. ID., ibid., doc. 802, pp. 391-393).

${ }^{25}$ En 1030, por ejemplo, aparece como uno más entre los clérigos de la diócesis: "Sampirus presbiter" (ed. ID., ibid., doc. 862, pp. 470-471).

${ }^{26} \mathrm{Se}$ deduce su nombramiento por el rey pamplonés porque éste ocupó León en el año 1034, desplazando a Vermudo III a Galicia, y porque el 13 de enero todavía aparecen: "Serenissimus princeps magnus Sancius Dei gratia rex pium et magnum... Sampirus presbiter" (ed. ID., Colección catedral de León, IV, doc. 924, pp. 3739), en tanto que el 28 de septiembre del mismo año: "Regnante Sanzius rex in Legione... Sampirus Astorizense sedis Dei gratia aepiscobus" (ed. ID., ibid., doc. 934, pp. 50-52).

${ }^{27}$ Por última vez es mencionado Sampiro en la ya citada carta de 11 de noviembre de 1042 (ed. RUIZ ASENCIO, Colección catedral de León, IV, doc. 1004, pp. 165-167).

${ }^{28}$ Las dos vesiones, interpolada y pura, de la Chronica Sampiri han sido detenidamente estudiadas y comparadas por PÉREZ DE URBEL, Sampiro, pp. 273-346.

${ }^{29}$ Por fortuna, el obispo don Pelayo de Oviedo dejó constancia para la posteridad del nombre del autor cuya crónica copió (vid. ID., ibid., p. 480).

${ }^{30}$ Vid. RUIZ ASENCIO, "La inclusión del 'Chronicon' de Sampiro en la 'Historia Silense", Archivos Leoneses, 54, 1973, pp. 228-279. Repetidamente citado aquí el texto de Sampiro, utilizamos también la versión castellana de Gómez-Moreno (Introducción a la Historia Silense, pp. XCVI-CIX) (= SAMPIRO, Crónica).

${ }^{31}$ Lo advirtió en su día Pérez de Urbel (Sampiro, p. 258). Compárese el texto de Sampiro sobre Alfonso III (ed. ID., ibid., pp. 275-308), con el de la Chronica Albeldensia (ed. J. GIL FERNÁNDEZ, J.L. MORALEJO y J.I. RUIZ DE LA PEÑA, Crónicas asturianas. Crónica de Alfonso III -Rotense y "A Sebastián"-, Crónica Albeldense -y "Profética"-. Introducción y edición crítica. Traducción y notas. Estudio preliminar, Oviedo 1985, pp. 176-181) (= Chronica Albeldensia, = Crónica de Alfonso III, en cuanto a las respectivas fuentes; = GIL FERNÁNDEZ, Crónicas asturianas, en cuanto al estudio). 
nos desde Alfonso III (866-910) y hasta Ordoño III (951-956), reinados de los que el autor sabe medidas anuales y mensuales, y una vez la diaria, que sin embargo ni se molesta en consignar con sus contemporáneos, los reyes Ramiro III (967-985) y Vermudo II (982-999) ${ }^{32}$. Y es asimismo sugerente la coincidencia de Sampiro con 'Îsà ar-Râzî al relatar el conflicto surgido entre Alfonso IV (926-931) y Ramiro II (931-951) en la lucha por el trono, lo que nos hace pensar en una posible fuente común $^{33}$ :

\section{SAMPIRO}

Alfonso, hijo de D. Ordoño, recibió el cetro paterno. Manteniéndose éste en el reino vínole deseo de tomar camino de penitencia, y empleándose en tales ocupaciones, envió emisarios por su hermano Ramiro, a tierras de Viseo, diciendo cómo quería renunciar al reino $\mathrm{y}$ cederlo a su hermano.

Vino Ramiro ciertamente a Zamora con todo el ejército de sus magnates, y recibió el reino, adelantándose por cierto su hermano a un monasterio, en el lugar que se llama de los Señores Santos (Sahagún), sobre la orilla del río Cea.

El cual Ramiro movilizó su ejército para perseguir a los árabes, y entrando en Zamora le vino emisario, porque su hermano Alfonso, salido del monasterio, habría recibido por segunda vez el reino de León.

Oyendo esto el rey, conmovido de ira mandó tocar las bocinas, vibrar las lanzas; volviendo veloz a León por segunda vez, lo sitió día y noche hasta que lo cogió, y preso, mandó echarlo a un calabozo.

Tramadas arterías ciertamente, todos los magnates asturianos enviaron emisarios a Ramiro en favor del susodicho príncipe.

Mas él, entrando en Asturias, cogió a todos los hijos de Fruela: Alfonso, que parecía regir el cetro paterno, Ordoño y Ramiro; los llevó consigo, los juntó con su hermano, el susodicho Alfonso, a quien tenía en un calabozo, y a todos juntos en un día mandó sacar los ojos. Había reinado, ciertamente, Alfonso siete años y siete meses. Año 931.

\section{'ÎSÀ AR-RÂZî}

(El poder) pasó al rey unánimemente aceptado, Alfonso, que ya no tuvo competidor. Posteriormente cambió de parecer, y llamando a su hermano Ramiro le entregó el reino, abdicó y se hizo monje, ingresando en uno de sus venerados monasterios, donde moró algún tiempo ajeno al poder...

(Ramiro) quiso salir con grandes ejércitos a tierra musulmana... para lo cual envió reclutadores por tierra cristiana y salió a Zamora, donde se quedó a esperar que se congregasen las tropas de la cristiandad. Entonces se reunieron con Alfonso el monje los enemigos de su hermano... con lo que, descubriendo la cara, abandonó el monacato y se salió del convento, aprovechando la ausencia de su hermano, al que se opuso en León... donde el obispo Oveco, vicario de Ramiro, y otros hombres de su confianza huyeron aquella noche, uniéndose al rey en Zamora, donde aún permenecía.

Desistió éste entonces de la campaña y se dirigió apresuradamente con las tropas que tenía reunidas a León, contra su hermano Alfonso, al que sitió allí... teniéndolo preso durante largo tiempo hasta que, habiéndose consolidado su poder y regresado a él Oveco, su reino quedó completo y su obediencia fue general...

Fue entonces cuando reunió a todos los hijos del rey (Fruela), cuyos propósitos de reinar temía, y los cegó, entre ellos a su hermano y competidor, Alfonso el monje, a los tres hijos, Alfonso, Ramiro Ordoño, de su (tío) el anterior monarca Fruela hijo de (Alfonso) y a algunos de sus sobrinos... acabando todo esto

\footnotetext{
${ }^{32}$ De otro modo es inconcebible. Resulta muy significativo su relato sobre la muerte de Ramiro II, del que sabe además con exactitud que reinó 19 años, 2 meses y 25 días (vid. PÉREZ DE URBEL, Sampiro, p. 331).

${ }^{33}$ SAMPIRO, Crónica, CII-CIII; IBN HAYYÂN, al-Muqtabis V, pp. 259-260.
} 
a principios del año 932.

Paralelismo que también tiene continuidad al relatar ambos autores la batalla de Simancas, de $939^{34}$ :

\section{SAMPIRO}

El rey Abderrahman se apresuró hasta Simancas con gran ejército. Nuestro católico rey, oyendo esto, dispuso ir hasta allá con gran ejército, y allí mismo, peleando uno con otro, en lunes, estando al caer la fiesta de los santos Justo y Pastor, fueron deshechos 80.000 de ellos. Aun el mismo Abohahia, rey agareno, allí fue cogido por los nuestros, y llevado a León y en el calabozo metido, porque traicionó a don Ramiro fue cogido por recto juicio de Dios. Mas aquéllos que habían quedado, tomando el camino, se volvieron fugitivos. Mas el rey, persiguiéndolos, cuando ellos llegaron a la urbe que se llama Alhandega, allí fueron cogidos y extinguidos por los nuestros. Mas el propio rey Abderrahman escapó semivivo. De donde los nuestros llevaron muchos despojos, a saber oro, plata y vestidos preciosos. El rey, ciertamente ya seguro, avanzó hacia su casa con gran victoria

\section{'ÎSÀ AR-RÂZî}

El ejército pasó a las puertas de Simancas el día siguiente, miércoles y presentó combate en la mañana que siguió a la noche del jueves, quedando 11 de šawwâl ( 8 de agosto), en un violentísimo encuentro, y nuevamente el viernes, siguiente día, encontrando los musulmanes gran entereza, pues aunque en un momento fueron rotas las líneas cristianas, se rehicieron y los rechazaron en vergonzosa desbandada, con enórmes pérdidas, y en la retirada, el enemigo los empujó hacia un profundo barranco, que dio nombre al encuentro (Alhándega), del que no pudieron escapar, despeñándose mucho y pisoteándose de puro hacinamiento: el califa, que se vio forzado a entrar allí con ellos, consiguió pasar con sus soldados, abandonando su real y su contenido, del que se apoderó el enemigo... Muhammad b. Hâšim quedó preso, en poder del tirano Ramiro hijo de Ordoño, que se aferró a su presa y le marcó subido rescate.

\section{3.- UN SIGLO DE CONSTANTE EXPANSIÓN TERRITORIAL (850-950).}

Conocidos sobradamente son, como para no abundar aquí en ellos, los pasajes de los más antiguos cronistas cristianos al respecto de los esfuerzos de Alfonso I de Asturias (739-757) y de su hermano Fruela Pérez para mantener un territorio yermo y despoblado desde las estribaciones montañosas del pequeño reino astur hasta las márgenes del río Duero y aún más allá. Así lo expresan tanto la Chronica Albeldensia (los que llaman Campos Goticos, hasta el río Duero, los asoló) ${ }^{35}$ y la Crónica de Alfonso III, que relaciona con paciencia gran cantidad de estas plazas: Lugo, Tuy, Oporto, Braga, Viseo, Chaves, Astorga, León, Saldaña, Mave, Amaya, Oca, Miranda de Ebro, Revenga, Alesanco, Cenicero, Albelda de Iregua, Carbonera, Osma, Coruña del Conde, Sepúlveda, Segovia, Simancas, Zamora, Ledesma y Salamanca, matando además por la espada a los árabes, y llevándose consigo a los cristianos a la patria; para añadir que por aquel tiempo se pueblan Primorias (en Astu-

\footnotetext{
${ }^{34}$ SAMPIRO, Crónica, p. CIV; IBN HAYYÂN, al-Muqtabis $V$, pp. 325-326.

${ }^{35}$ Chronica Albeldensia, p. 248.
} 
rias), Liébana, Transmiera (en Cantabria), Sopuerta (en Vizcaya), Carranza (en Vizcaya), las Vardulias, que ahora se llaman Castilla y la parte maritima de Galicia; pues Álava, Vizcaya, Alaone (?) y Orduña está comprobado que siempre estuvieron en poder de sus habitantes, como Pamplona, que es Degio (Monjardín) y Berrueza ${ }^{36}$.

La situación comienza a cambiar sensiblemente un siglo después, y ya a mediados del IX, los cristianos, al mando de Ordoño I (850-866), ocupan algunas de las importantes plazas desiertas del sur, tales como Tuy, Astorga, León y Amaya, según el testimonio de la Chronica Albeldensia: Pobló León y Astorga, junto con Tuy y Amaya, y fortificó muchas otras plazas ${ }^{37}$; coincidente con el de Alfonso III: Las ciudades de antiguo abandonadas, es decir, León, Astorga, Tuy y Amaya Patricia, las rodeó de muros, les puso altas puertas, y las llenó de gentes, en parte de las suyas, en parte de las legadas de España ${ }^{38}$.

Luego, el propio Alfonso III (866-910) da el gran impulso conquistador y repoblador al que se refiere un contemporáneo, el repetido autor de la Chronica Albeldensia: Asoló Coimbra, en poder de los enemigos, y luego la pobló con gallegos, y sometió muchas otras plazas. En su tiempo crece la Iglesia y se amplía el reino. También son pobladas por cristianos las ciudades siguientes: la primera Braga, la segunda Oporto, la tercera Orense, la cuarta Eminio, la quinta Viseo, y la sexta Lamego ${ }^{39}$. De cuyo testimonio da cuenta también, siguiéndole, la Crónica de Sampiro: Defendió a Coimbra, sitiada por enemigos, y la subyugó a su imperio. Cedieron también a sus armas muchísimas urbes de España. En su tiempo también fue ampliada la Iglesia, porque las ciudades de Oporto, Braga, Viseo, Chaves y Oca se pueblan por los cristianos, y según decisión canónica se ordenan obispos, y se prosigue poblando hasta el río Tajo ${ }^{40}$; añadiendo un poco más adelante: Mandó poblar urbes desiertas de antiguo; estas son: Zamora, Simancas y Dueñas y todos los Campos Góticos, pues Toro se la dio para poblar a su hijo García ${ }^{41}$.

\footnotetext{
${ }^{36}$ Crónica de Alfonso III, p. 209. La identificaciones propuestas son del traductor, José L. Moralejo.

${ }^{37}$ Chronica Albeldensia, 249. Anales Castellanos Primeros: "In era DCCCLXLIIII populabit domnus Ordonius Legione" (ed. hasta la época alfonsí, GIL FERNÁNDEZ, Crónicas asturianas, p. 77). En los Annales Compostellani: "Era DCCCXCVIII. Populavit Rodericus comes Amajam mandato Ordonii regis" (España Sagrada, $=$ ES, XXIII, p. 318).

${ }^{38}$ Crónica de Alfonso III, p. 218.

${ }^{39}$ Chronica Albeldensia, pp. 250-251.

${ }^{40}$ SAMPIRO, Crónica, p. XCVIII. El famoso documento de Odoino sitúa al frente de la repoblación de Chaves ("ciuitatem Flauias"), en el año 872, al "illustrissimo uiro domni Odoario digno bellatore... era DCCCCX" (ed. A. LÓPEZ FERREIRO, Historia de la S.A.M. Iglesia de San iago de Compostela, Santiago 1899, II, doc. 75, 176-186).

${ }^{41}$ SAMPIRO, Crónica, pp. XCVIIII-XCIX.
} 
Y la repoblación de Ubierna y Burgos, en 884, se producen asimismo durante su reinado, por mano del conde Diego Rodríguez, a las que siguió luego Cardeña unos años después, en $899^{42}$.

Muerto Alfonso III, su hijo García (910-913), el reciente repoblador de Toro, habiendo alcanzado el trono, continuó la labor paterna en el Duero oriental, al tomar tres de sus condes, en 912, las plazas de Roa, Aza, Coruña del Conde, San Esteban de Gormaz y Osma, según nos transmiten los Anales Castellanos Primeros: In era DCCCCL populaverunt comites Monnio Nunniz, Rauda; et Gondesalbo Telliz, Hocsuma; et Gundesalbo Fredenandiz Aza et Clunia et Sancti Stefani justa fluvius Doyri $^{43}$. A todas las cuales siguió Sepúlveda en 940, reinando Ramiro II y por mano de Fernán González: Era DCCCCLXXVIII populavit Fredinandus Gundisalviz Septempublica ${ }^{44}$.

Es muy conocido el pasaje de Sampiro al respecto de la repoblación leonesa en el Tormes, con su capital, Salamanca ${ }^{45}$, que fue confiada al conde Vermudo Núñez, según Ibn Hayyân ${ }^{46}$. Y otros testimonios, de tipo cronístico, documental, epigráfico, monumental o toponímico, nos ilustran además sobre otras plazas extremas, en torno al Duero medio, que ya se encontraban en poder de los cristianos durante la primera mitad del siglo $\mathrm{X}$, todas ellas recogidas en su día por Ruiz Asencio: Wamba, Castrodeza, San Cebrián de Mazote, Adalia (más al sur), Villalbarba y San Román (en la línea del río Hornija); Tordesillas y Alkamín (muy próxima), sobre el mismo Duero; Trigueros, Cabezón y Simancas, en la línea del bajo Pisuerga; Mamblas y Villa Albura (en la desembocadura del Jaramiel); Portillo, Mojados, Alcazarán, Íscar, Olmedo y Coca (en las

\footnotetext{
${ }^{42}$ En los Annales Compostellani: "Era DCCCCXXII populavit Didacus comes Burgos mandato Aldephonsi regis. Era DCCCCXXXVII. Fuit Cardeña populata" (ES, XXIII, p. 318). En los Annales Complutenses: "Sub Era DCCCCXX(II). Populavit Didacus comes Burgos et Ovirna" (ibid., p. 310).

${ }^{43}$ Vid. al respecto de esta repoblación, PÉREZ DE URBEL, El Condado de Castilla, I, 1969, pp. 243-279.

${ }^{44}$ Vid. ID., ibid., II, 1970, pp. 121-136. Sepúlveda hubo de ser asaltada años después por Almanzor, en 979 (Dikr bilâd al-Andalus, p. 197).

${ }^{45}$ SAMPIRO, Crónica, p. CIV: "Después (de la victoria de Simancas, en agosto de 939), al segundo mes, dispuso que fuese una expedición a la ribera del Tormes, y allí pobló ciudades desiertas. Son estas Salamanca, residencia antigua de campamentos, Ledesma, Ripas (?), Baños, Albandegua (?), Peña (?) y otros muchos castillos, que sería largo ennumerar".

${ }^{46}$ Ibn Hayyân dice que "Bermudo Núñez, conde de Salamanca" fue derrotado en 942 (al-Muqtabis V, p. 364), y sabemos que participó en la repoblación de la ciudad, por una carta de Ordoño III del 953: "populatores patris mei qui fuerunt de Legione, id est: patri domno Ouecco episcopo, Iusiuado, Ueremudus Nunniz, Fortis, Furtunius et Pelagius prebiter" (ed. E. SÁEZ y C. SÁEZ, Colección documental del Archivo de la catedral de León -775-1230-, II -953-983-, León 1990, doc. 260, pp. 4-7) (= SÁEZ, Colección catedral de León, II). Vid. SAMPIRO, Crónica, p. CIV.
} 
vegas del Cega, Eresma y Adaja) ${ }^{47}$; además de Peñafiel y Sacramenia (en el Duratón), bajo el conde de Monzón, Assur Fernández ${ }^{48}$.

\section{4.- LA SITUACIÓN GEOPOLÍTICA LEONESA A MEDIDADOS DEL SIGLO X.}

Frente al califato, cuyo territorio era llamado con el enigmático nombre de al-Andalus por los musulmanes, y España por los cristianos del norte, el cronista leonés Sampiro nos brinda un panorama general de los tres estados norteños durante el siglo X: Estos son, el reino de los francos, el reino de Pamplona, también el reino de León ${ }^{49}$. Este último, llamado Yillîqiyya por los musulmanes, en alusión a la antigua "Gallaecia" romana ${ }^{50}$, se dividía a su vez en cuatro provincias o grandes territorios: Galicia, Asturias, Castilla, y la tierra foramontana aquende el Duero $^{51}$. A su vez, la tierra foramontana comprendía, al oeste, los territorios de importantes ciudades como Astorga, Zamora y León, y, al este, los muy extensos Campos Góticos, bañados por los ríos Esla, Cea, Valdera-

\footnotetext{
${ }^{47}$ Vid. RUIZ ASENCIO, "La provincia de Valladolid en la alta Edad Media", Historia de Valladolid. II. Valladolid Medieval, 1980, pp. 11-46 (= RUIZ ASENCIO, La provincia de Valladolid). Según un autor cordobés en 939 el califa "con un escuadrón enviado desde Toledo... saqueó la zona de Coca, haciendo muertos y cautivos y regresando victorioso y con botín" (IBN HAYYÂN, al-Muqtabis V, p. 339).

${ }^{48}$ Sabemos que Peñafiel aún era cristiana en 975 (ID., Anales palatinos, p. 276). Y Sacramenia fue atacada por Almanzor en 983 (Dikr bilâd al-Andalus, p. 198).

${ }^{49}$ SAMPIRO, Crónica, p. CIX. En una carta leonesa de 937 se dice: "Regnante domno Ranimiro principe Legionense sedis, dominante populo christianorum in fide katolica" (ed. E. SÁEZ, Colección documental del Archivo de la catedral de León -775-1230-, I -775-952-, León 1987, doc. 121, pp. 189-190) (= SÁEZ, Colección catedral de León, I). Son numerosos, por otra parte, los testimonios documentales y cronísticos, que llaman Hispania al califato, como poseedor de la más grande porción de tierra del antiguo reino visigodo; así la Crónica de Alfonso III, al referir la invasión árabe durante el reinado de Rodrigo: "Anno regni regni illius tertio ob causam fraudis filiorum Uitizani Sarrazeni ingressi sunt Spaniam" (ed. GIL FERNÁNDEZ, Crónicas asturianas, p. 120); la Chronica Albeldensia, hablando del rey Silo: "Cum Spania ob causam matris pacem habuit" (ed. ID., ibid., 174); y la Chronica Sampiri, al señalar cómo cedieron ante Alfonso III "plurime Yspanie vrbes" (ed. PÉREZ DE URBEL, Sampiro, p. 281). Para no alargar mucho, sólo añadir un diploma de Sancho I del año 960, a los dos años de volver de Córdoba: "anno regni nostri IIII et de adventu Spanie II" (ed. J. Ma . MÍNGUEZ FERNÁNDEZ, Colección diplomática del monasterio de Sahagún, siglos IX y X, León 1976, doc. 175, pp. 216-218) (= MÍNGUEZ, Colección diplomática de Sahagún).

${ }^{50}$ Así lo advierten VIGUERA y CORRIENTE (Crónica, p. 446), que definen Yillîqiyya como "el territorio en ese tiempo capitalizado en León"; perfectamente diferenciado de "Galîsiyya, que designa el extremo NO de modo específico". Diferenciación que se ajusta a lo que también nos dicen los diplomas. En efecto, el obispo Frunimio I de León, en 874, hace una donación a su iglesia, que se encuentra "in ciuitate que uocitatur Legio, territorio Gallecie" (ed. SÁEZ, Colección catedral de León, I, doc. 6, pp. 13-14); y en otra escritura de 946,

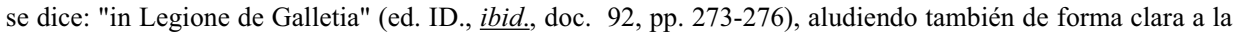
antigua provincia Gallaecia romano-visigoda, que llegaba hasta el río Cea, como recuerda otra carta de Sahagún del año 922, sin mácula, que sitúa este monasterio "super ripam fluminis cui nomen est Zeia, finibus Gallecie" (ed. MÍNGUEZ, Colección diplomática de Sahagún, doc. 29, pp. 60-61).

${ }^{51}$ Alfonso V recuerda, en 1012, su coronamiento "in sedis Legione", al que asistieron en 999 "omnem togam palatii, episcopi et conmites Kastelle seu Gallecie necnon et Asturiense" (ed. RUIZ ASENCIO, Colección catedral de León, III, doc. 706, pp. 263-265); y así en otra carta de 1007: "et collecto concilio Castelle, terre Forizense, Galliciense uel Asturiense, leauauerunt eum regem" (ed. J. Ma. FERNÁNDEZ DEL POZO, "Alfonso V rey de León", León y su Historia V, León 1984, doc. IV, pp. 234-238).
} 
duey, Carrión y hasta el límite del Pisuerga, con importantes núcleos urbanos y defensivos como Coyanza, Cea, Saldaña, Carrión, Monzón, Toro y Simancas ${ }^{52}$. Allende el Duero, esto es, a lo largo de toda la extremadura, se ubicaba pues la tierra fronteriza del reino de León, cuyas plazas nos hemos propuesto mencionar al hilo de la divisoria imaginaria trazada por Ibn Hayyân, desde Santarén a Huesca; línea que atraviesa todo el sistema montañoso central que separa las dos submesetas norte y sur, situado precisamente en el territorio comprendido entre los ríos Duero (cristiano) y Tajo (musulmán), que compartieron ambos contendientes, cara a cara, durante las décadas centrales del siglo $X$.

Por lo que respecta al reino de Pamplona, desde que los descendientes del régulo Íñigo Arista fueron desplazados por Sancho Garcés I $(905-926)^{53}$, tanto éste como su sucesor García Sánchez I (925-970) y su madre y turora la reina Toda, tuvieron continuos contactos de tipo político y militar, siempre de sincera subordinación, con los monarcas leoneses Alfonso III (866-910), García (910-913), Ordoño II (914-924), Alfonso IV (926-931) y Ramiro II (931-951), a los que piden auxilio cuando es necesario y con los que colaboran de forma activa cuando son requeridos $^{54}$; hasta que con Ordoño III (951-956) los reyes pamploneses

\footnotetext{
${ }^{52}$ Que León era "tierra foramontana" lo dice expresamente una carta de 1002: "uillas prenominatas in terris foris montaine in urbem Legionense" (ed. RUIZ ASENCIO, Colección catedral de León, III, doc. 629, pp. 162-165). Alfonso III repobló en 899, según la Chronica Sampiri: "Çemora, Septimancas et Donnas uel omnes Campi Gotorum; Taurum namque dedit ad populandum filio suo" (ed. PÉREZ DE URBEL, Sampiro, 305). Los grandes condes de Tierra de Campos se documentan en ocasiones junto al de Castilla en la corte leonesa, según carta de 950: "Fredinandus Gundisalvis comes Castelle... Didacus Monnioz comes Saldanie... Vermudus Nunnez comes in Ceie" (ed. MÍNGUEZ, Colección diplomática de Sahagún, doc. 129, pp. 166167); a los que cabe añadir "Assur Fredinandiz in Montson", en cuyo distrito se ubicaban las plazas de Peñafiel y Sacramenia, según una carta de Cardeña del año 943: "enim vero ipsum locum iam supradictum sit a parte de meo condato vel in iure de ipsis castellis que in circuito eius sunt, id est, unum Penna fidele et alterum Sacramenia" (reg. J. RODRIGUEZ, Ramiro II, rey de León, Madrid 1972, doc. 48, p. 642). Y en efecto, Ibn Hayyân (Anales palatinos, p. 276) llama conde de Peñafiel a su hijo Fernando Ansúrez, con motivo de la campaña leonesa contra Gormaz del año 975: "Fernando ibn Al-Sur, señor de Peñafiel y de sus contornos".

${ }^{53}$ En una Additio de regibvs Pampilonensibvs escrita en el año 976, que traen algunos textos de la Chronica Albeldensia, se dice: "surgió en Pamplona un rey de nombre Sancho Garcés... conquistó, en Cantabria, desde la ciudad de Nájera hasta Tudela, todas las plazas fuertes. Desde luego la tierra de Degio, con sus villas, la poseyó entera. La tierra de Pamplona la sometió a su ley, y conquistó asimismo todo el territorio de Aragón con sus fortalezas" (trad. MORALEJO, Crónicas asturianas, 263). Sobre las dos dinastías de Pamplona y el triunfo de la Jimena sobre la Íñiga, vid. SÁNCHEZ-ALBORNOZ, "Los vascos y los árabes durante los primeros siglos de la Reconquista"; ID., "Problemas de la historia de Navarra del siglo IX"; ID., "Otra vez los Jimenos de Navarra", Miscelánea de Estudios Históricos, León 1970, pp. 187-204, 293-352 y 367-380).

${ }^{54}$ Sobre el papel de Alfonso III en apoyo de la nueva dinastía Jimena vid. ID., ibid., pp. 293-352. Sin embargo, Sancho Garcés I apoyó luego la rebelión del primogénito leonés, García: "Pusieron en su lugar a García, a quien se unieron los reinos de Pamplona, en el oriente del país... hasta Asturias, detrás de los montes" (IBN HAYYÂN, al-Muqtabis, 103). Sancho solicitó con frecuencia el auxilio de Ordoño, al que también apoyó decididamente; varias son las citas de Ibn Hayyân a este respecto, en 915: "Salió el tirano Ordoño... haciendo leva de cristianos desde el confín de Pamplona" (ID., ibid., p. 100); en 918: "En este año movilizaron el tirano Ordoño... y el vascón Sancho" (ID., ibid., 117); en 920: "Los bárbaros Ordoño... y Sancho... salieron al encuentro del ejército musulmán" (ID., ibid., p. 127); y la Chronica Sampiri, en 923: "Rex vero Sancius Garsiani
} 
comienzan a intervenir activamente en la política interna leonesa en términos de igualdad, apoyando las aspiraciones de Sancho I (956-966), encarcelando al conde de Castilla en 960, y vigilando la minoría de niño Ramiro III desde la misma capital leonesa ${ }^{55}$. Las estrechas relaciones de parentesco que unieron durante el siglo $\mathrm{X}$ a todos estos protagonistas, extensibles de igual modo a los califas cordobeses, a los Banû Qasî del Ebro y al mismísimo Almanzor, quedan registradas a continuación ${ }^{56}$ :

filius misit ad regem domnum Ordonium, vt adiuvaret eum contra acies agarenorum" (ed. PÉREZ DE URBEL, Sampiro, p. 313). En la lucha contra su primo Alfonso Froilaz, Alfonso IV fue apoyado por "su suegro, Sancho hijo de García, señor de Pamplona" (IBN HAYYÂN, al-Muqtabis, p. 259). Y Ramiro II, recibió en Simancas "refuerzos de los confines de Pamplona" (ID., ibid., p. 330). Y son ejemplos muy fácilmente ampliables, pues Ramiro II intervino en tierras de Zaragoza cuando le plugo, según la Chronica Sampiri (ed. PÉREZ DE URBEL, ibid., p. 324), y asoció en el tratado de paz firmado con Córdoba en 941 "al señor de Pamplona" (IBN HAYYÂN, ibid., p. 351).

${ }^{55}$ La misma Chronica Sampiri nos cuenta cómo Ordoño III fue amenzado por sendos ejércitos de "Garsiano rege Pampilonensium, necnon et Fredenandus Gundissaluiz Burgensium comes", que apoyaban la candidatura de Sancho el Gordo (ed. PÉREZ DE URBEL, Sampiro, pp. 332-33); y ya no tuvo autoridad para asociar a García I de Pamplona en el tratado de paz que firmó con Córdoba en 956, del que nos habla Ibn Jaldún: "En el año 45 mandó pedir la inclusión (en el referido acuerdo) de Fernán González, conde de Castilla... y An-Nâsir accedió a lo solicitado por Ordoño hijo de Ramiro" (IBN JALDÛN, Historia de los árabes de España, trad O. A. MACHADO MOURET, Cuadernos de Historia de España, 45-46, 1967, p. 342). Un contingente pamplonés permaneció en León al lado de Sancho I y Ramiro III, según se deduce de algunas cartas, entre las cuales una de 962: "Ramirus Garseani prolis et provincie Pampilonie" (ed. MÍNGUEZ, Colección diplomática de Sahagún, doc. 196, pp. 140-242). En los Annales Compostellani: "Era DCCCCXCVIII. Fuit captus comes F. Gondisalvi et filii ejus in Aconia a rege Garsia, et transmisit illos in Pampillis" (ES, XXIII, p. 319).

${ }^{56}$ Vid. los cuadros publicados por SÁNCHEZ-ALBORNOZ, Problemas de la historia e Navarra en el siglo X, pp. 336-337. Ibn Hayyân se hace eco del estrecho parentesco entre la reina Toda y el califa, pues eran tía y sobrino: "Toda, hija de Aznar que se acogía a su obediencia e invocaba los vínculos de sus antepasados con los del califa, pidiéndole que le concediera la paz y alejara a la caballería" (al-Muqtabis, 252). Sabemos que volvió a invocar su parentesco en 958. 


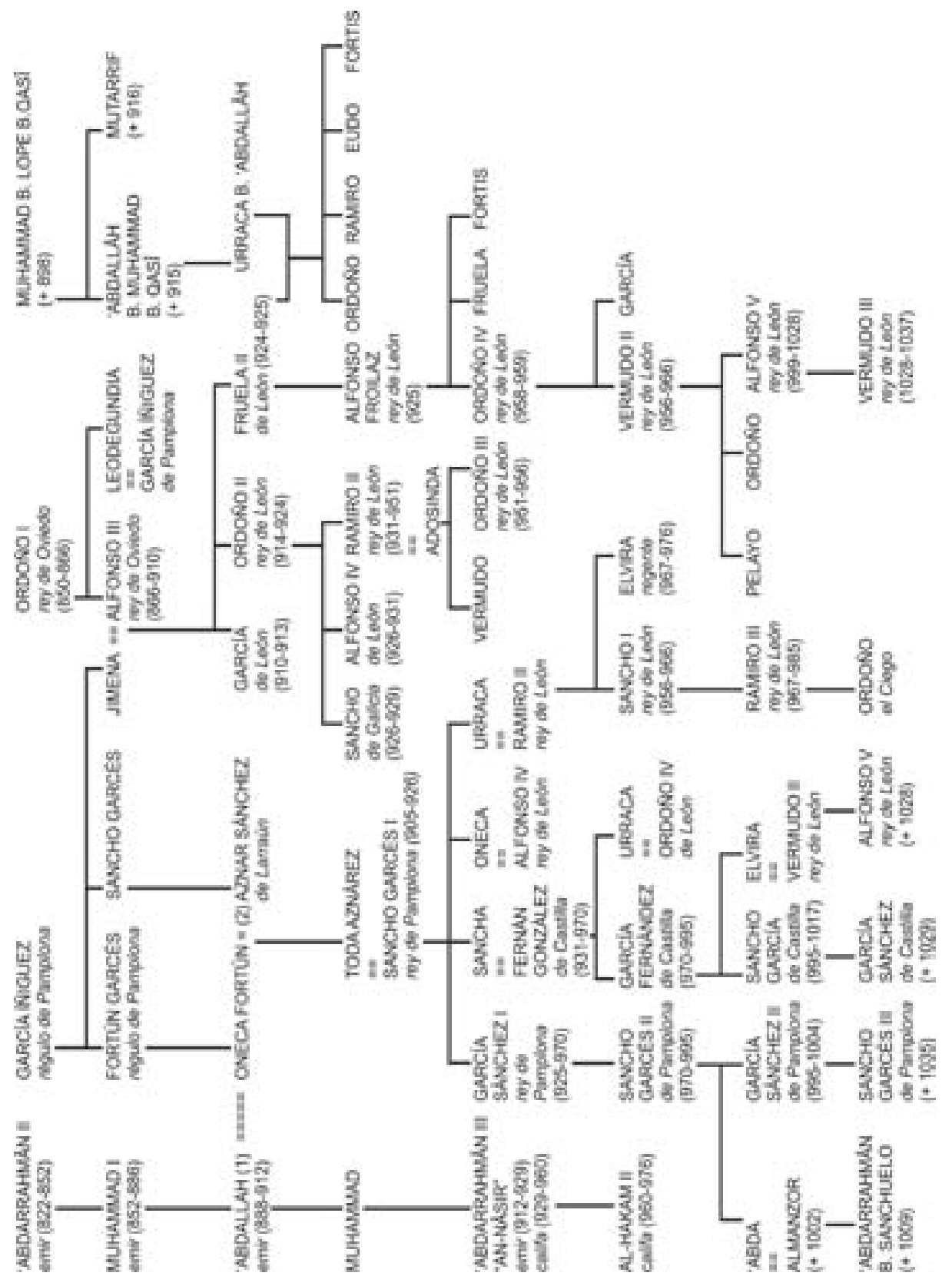




\section{5.- LA ACTIVIDAD FRONTERIZA DE RAMIRO II.}

Fueron las rebeliones internas una constante durante los primeros veinticinco años del reinado de Abdarrahmân III an-Nâsir y sería largo ennumerar aquí el número de las ciudades y plazas a las que el califa sometió finalmente a su autoridad $^{57}$. Y en este contexto, la situación de los distritos fronterizos musulmanes no fueron una excepción, al contrario, tales disidencias provocaron muy delicadas y peligrosas situaciones, que los reyes de León se cuidaron muy bien de capitalizar en su favor.

En efecto, a lo largo de toda la línea fronteriza, tenemos noticia de la desobediencia, por poner varios ejemplos, de Santarén (937), Évora (915), Badajoz (929), Mérida (938), Talavera (937), Toledo (930), Zorita (926), Calatayud (924), Maluenda (934), Daroca (935), María (935), Zaragoza (935), Rueda de Jalón (934), Tudela (923), Huesca (937) y Barbastro (935). Es curioso observar cómo cuatro de las más importantes (Santarén, Toledo, Catalayud y Zaragoza) buscaron de forma directa el auxilio de los leoneses. Y en este sentido, la política de Ramiro II parece haber sido, como era obligado, muy oportunista:

-- Año 932 (Alianza con Toledo): Los pertinaces toledanos, acosados por el duro asedio... habían pedido ayuda a sus vecinos, los enemigos infieles... les enviaron un gran refuerzo de sus mejores guerreros ${ }^{58}$.

-- Año 932 (Ataque a Madrid): Ramiro... reunido ejército, avanzando a la ciudad que se llama Madrid, destrozó sus muros e hizo grandísimos estragos ${ }^{59}$.

-- Año 933 (Defensa de Osma): Mas residiendo (Ramiro) en León vino emisario de Fernán González sobre grande expedición que adelantaba hacia Castilla. Lo que oído, movilizó el ejército el rey, y salió al encuentro de ellos en el lugar que se dice Osma... dióle el Señor gran victoria ${ }^{60}$.

-- Año 934 (Defensa de Clunia): Se detuvo (An-Nâsir en Clunia)... encontrando congregados a los infieles en ella, pues habian entrado con caballeros e infantes... con ellos estaba su rey, el tirano Ramiro hijo de Ordoño, y todos los condes ${ }^{61}$.

\footnotetext{
${ }^{57}$ Vid., al respecto, las constantes referencias de IBN HAYYÂN, en su al-Muqtabis $V$, pues son numerosísimas las plazas que hubo de someter el califa.

${ }^{58}$ ID., ibid., p. 238.

${ }^{59}$ SAMPIRO, Crónica, p. CIII.

${ }^{60}$ ID., ibid., p. CIII.

${ }^{61}$ IBN HAYYÂN, al-Muqtabis $V$, p. 255.
} 
-- Año 935 (Paz con Córdoba): En este año an-Nâsir hizo la paz con Ramiro hijo de Ordoño... tras pedírsela aquél con repetidos mensajeros ${ }^{62}$.

-- Año 936 (Alianza con Zaragoza): Violó el tirano Ramiro hijo de Ordoño, señor de Yillîqiyya, a quien Dios maldiga, la paz, al pedirle socorro el rebelde Muhammad b. Hâšim, señor de Zaragoza, contra los musulmanes ${ }^{63}$.

-- Año 936 (Apoyo a Zaragoza): Reunido un ejército, (Ramiro II) avanzó a Zaragoza... subyugó todos los castillos que Abohahia tenía hostiles y se los entregó y volvió a León con gran victoria ${ }^{64}$.

-- Año 937 (Alianza con Calatayud): Mutarrif b. Mundir at-Tuyîbî, apodado Ibn Šuwayrib ("bigotito"), señor de Calatayud... había pedido apoyo a los infieles de Álava y al-Qilâ', que le vinieron en gran número con sus nobles y caballeros ${ }^{65}$.

-- Año 938 (Encuentro en la Frontera Inferior): En este año, an-Nâsir envió al caíd Ahmad b. Muhammad b. Ilyas de campaña contra los leoneses de occidente... los derrotó e hizo una carnicería entre ellos... enviándoles 200 cabezas cortadas, de zamoranos especialmente ${ }^{66}$.

-- Año 939 (Alianza con Santarén): El traidor Umayya b. Ishâq alQurašî, rebelde en ella contra an-Nâsir y seductor de la población, que fue al tirano Ramiro hijo de Ordoño a pedirle ayuda contra el islam ${ }^{67}$.

-- Año 939 (Defensa de Simancas): El rey cordobés Abderrahman se apresuró hasta Simancas con gran ejército. Nuestro católico rey (Ramiro), oyendo esto, dispuso ir hasta allá con gran ejército... fueron deshechos ${ }^{68}$.

-- Años 939-940 (Repoblación del Tormes): Después (de Simancas), al segundo mes, (el rey Ramiro) dispuso que fuese una expedición a la ribera del Tormes, y allí pobló ciudades desiertas ${ }^{69}$.

-- Año 940 (Paz con Córdoba): En este año fueron frecuentes las cartas de Ramiro hijo de Ordoño, rey de los leoneses, pidiendo la paz y tregua $^{70}$.

\footnotetext{
${ }^{62}$ ID., ibid., pp. 273-274.

${ }^{63}$ ID., ibid., p. 283.

${ }^{64}$ SAMPIRO, Crónica, p. CIII.

${ }^{65}$ IBN HAYYÂN, al-Muqtabis $V$, pp. 295-296.

${ }^{66}$ ID., ibid., p. 318.

${ }^{67}$ ID., ibid., pp. 321-322.

${ }^{68}$ SAMPIRO, Crónica, p. CIV.

${ }^{69}$ ID., ibid., p. CIV.
} 
-- Año 941 (Paz con Córdoba): Este año quedó completa la paz con el tirano Ramiro hijo de Ordoño ${ }^{71}$.

-- Año 942 (Ataque a Tudela): Cuando el enemigo de Dios, Ramiro hijo de Ordoño, conoció la aparición de los turcos en la Marca de Lérida y el pavor de los musulmanes de aquella zona, pretendió aprovecharse... juntando fuerzas se dirigieron a Tudela ${ }^{72}$.

-- Año 942 (Encuentro en la Frontera Media): Llegó carta del caíd del Centro, Ahmad b. Ya'là b. Wahb, comunicando su victoria sobre los hombres que a su zona había enviado el enemigo de Dios, Ramiro ${ }^{73}$.

\section{6.- ¿TIERRA DE NADIE? : IDHANA, CORIA, ÁVILA, SEGOVIA.}

Entre la línea fronteriza leonesa más exterior (Condeixa - Baños de Montemayor - Coca - Riaza - Gormaz) y la cordobesa (Santarén - Alcántara - Talavera - Talamanca - Atienza), que discurren a un lado y otro de la línea transversal imaginaria citada por Ibn Hayyân (de Santarén a Huesca), a lo largo de las sierras de Gata, Gredos y Guadarrama se encuentra un territorio alargado de soberanía indeterminada y de forma triangular (de oeste a este), más ancho en su lado occidental (de Coimbra a Santarén), y progresivamente más estrecho hacia el oriente (de Gormaz a Atienza), hasta cerrarse el vértice en la sierra del Moncayo y hacerse inexistente en la apretada frontera navarro-cordobesa del Ebro y del Gállego (desde Tarazona a Boltaña). Una posible "tierra de nadie" en cuyo suelo se encontraban ciudades tan significadas como Idhana (Egitania), Coria, Ávila y Segovia, cuatro antiguos obispados visigodos que quedaban situados en la misma línea fronteriza imaginaria trazada por el historiador cordobés sobre las cadenas montañosas centrales ${ }^{74}$.

En efecto, ya el autor de la Chronica Albeldensia consignó cómo Alfonso III, después de repoblar hasta el Mondego, asoló y destruyó,

\footnotetext{
${ }^{70}$ IBN HAYYÂN, al-Muqtabis $V$, p. 340.

${ }^{71}$ ID., ibid., p. 351.

${ }^{72}$ ID., ibid., p. 364.

${ }^{73}$ ID., ibid., p. 364.

${ }^{74}$ Las plazas musulmanas con gobernardor califal, a lo largo de toda la frontera peninsular, eran: Lisboa (Ahmad b. 'Amr, en 937), Santarén (Mutarrif b. Yarrâh, en 942), Évora ('Abdalmalik b. Bišr, en 929), Badajoz (Ahmad b. Muhammad y 'Abbâs b. 'Abdallâh, en 942), Mérida (Muhammad b. Ya'là, en 941), Trujillo (Barâ' b. Muqâtil, en 931), Talavera (Muhammad b. Ahmad b. Maslama, en 941), Toledo (Ilyâs b. Sulaymân, en 942), Madrid (al-Fath b. Yahyà, en 940), Talamanca (García b. Ahmad, en 929), Zorita (Yahyà b. Asbag, en 936), Guadalajara (Ahmad b. Nuwayra, en 940), Atienza (Sâkir b. Fâjir, en 938), Catalayud (Hakam b. Mundir, en 940), Zaragoza (Muhammad b. Hâšim at-Tuyîbî, en 942), Tudela (Ahmad b. Muhammad, en 936), Huesca ('Abdalmalik b. Mûsà, en 940), Barbastro, Alquézar y Boltaña (Walîd b. at-Tawîl, en 942), Lérida y Balaguer (Yahyà b. Hâšim, en 938) y Tortosa ('Abdarrahmân b. Muhammad, en 940). Vid. ID., ibid., pp. 193, $237,293,312,321,348,354$ y 368 .
} 
consumiéndolas por la espada y por el hambre, Coria, Idanha y los demás confines de Lusitania, continuando luego con incursiones más profundas, hasta Mérida y hasta las orillas del mar $^{75}$. Y Sampiro añade a esto que durante el mismo reinado según decisión canónica se ordenan obispos, y se prosigue poblando hasta el río Tajo ${ }^{76}$. Lo que nos hace pensar en un verdadero intento de Alfonso III por ocupar dicho territorio, pues en la corte cristiana se documentan, al final del siglo IX y comienzos del siglo X, los prelados Teodomiro de Egitania (897-905) ${ }^{77}$ y Jacobo de Coria (899-915) ${ }^{78}$, obispos que, según parece, nunca llegaron a residir en unas ciudades que, por otro lado, tampoco fueron incluidas por los autores musulmanes (Ibn Hayyân, Ibn Hawqal, al-'Udrî y el Dikr) entre los dominios de Córdoba durante el siglo X. De hecho, cuando estos dos pontífices "in partibus infidelium" fallecen, ya no se nombran sucesores en ambas sedes durante todo el siglo $X$, de donde se deduce que no se pudo perfeccionar la pretendida repoblación de la tierra comprendida entre el Duero y el Tajo occidental, mencionada por la fuente de la que se sirvió Sampiro $^{79}$. Una repoblación que en el extremo occidente se detuvo en la línea del río Mondego (con Coimbra, Condeixa y Montemayor) ${ }^{80}$, y que en la Meseta central hubo de tener como puntos más avanzados, por un lado, Alba de Tormes y la tierra de Béjar, y más concretamente la plaza de Baños de Montemayor (el primero de la larga serie de objetivos

\footnotetext{
${ }^{75}$ Chronica Albeldensia, pp. 250-251.

${ }^{76}$ SAMPIRO, Crónica, p. XCVIII.

${ }^{77}$ Teodomiro de Egitania viene, entre otras, en una carta, hoy no discutida, del año 899 (ed. ES, XIX, pp. 340344). Vid. SÁNCHEZ-ALBORNOZ, "Sobre el acta de consagración de la iglesia de Compostela", Orígenes de la nación española. El reino de Asturias, III, Oviedo 1975, pp. 817-831 (= Orígenes).

${ }^{78}$ Jacobo de Coria suscribe nada menos que nueve cartas entre 899 (ed. ES, XIX, pp. 340-344) y 922 (ed. SÁEZ, "Notas al episcopologio minduniense del siglo X", Hispania, VI, 1946, p. 6, quien incorrectamente cree que el amanuense copio "Iacobus" por "Iohannes", nombre inadmisible entre los obispos de comienzos del siglo $\mathrm{X})$.

${ }^{79}$ Chronica Sampiri: "Et secundum sentenciam canonicam episcopi ordinantur, et usque ad flumen Tagum populando producitur" (ed. PÉREZ DE URBEL, Sampiro, p. 281); el testimonio da una idea clara sobre el optimismo repoblador del momento, y bien podría conectar con el nombramiento de Teodomiro de Egitania y Jacobo de Coria, o el refugio de ambos en Oviedo, durante las tareas expansivas. Aunque tampoco cabe descartar que la frase esté tomada por Sampiro de la Chronica Albeldensia: "Istius (Alfonso III) uictoria Cauriensis, Egitaniensis et ceteras Lusitanie limites gladio et fame consumte usque Emerita atque freta maris heremauit et dextruxit" (ed. GIL FERNÁNDEZ, Crónicas asturianas, p. 177).

${ }^{80}$ Coimbra y Condeixa fueron objetivo insistente de Almanzor en 986 y 987, según al-'Udrî (trad. RUIZ ASENCIO, Campañas, p. 64). Montemayor fue atacada por el general cordobés en el año 990 (Dikr bilâd alAndalus, p. 200). Y más al noreste, Trancoso era cristiana en 936 ("el visir Yahyà b. Isaq, salió... de Badajoz, en algara contra los leoneses de occidente, a quienes Dios destruya, conquistando las fortalezas de .rb.gueira y Trancoso"; IBN HAYYÂN, al-Muqtabis V, p. 285), y hubo de ser asaltada por Almanzor en 981 ("hizo Muhammad ibn Abî 'Âmir la campaña de Trancoso"; al-'Udrî, 61, RUIZ ASENCIO, ibid., 51, nota 15, prefiere Tarancueña, al no haber reparado tal vez en el Trancoso portugués), en el transcurso de la decimoquinta campaña ("la de Trancoso, que conquistó por las armas; Dikr bilâd al-Andalus, p. 198).
} 
que se marcó luego el terrible Almanzor desde el año $977^{81}$ ), y por otro las localidades segovianas de Armuña (también combatida por el hagib en $980^{82}$ ) y Riaza (objetivo del califa an-Nâsir, en 939) ${ }^{83}$.

En efecto, aunque los obispos de Ávila no son mencionados en ningún caso durante la décima centuria, en la ciudad de Segovia sí que encontramos otro intento de los leoneses por alcanzar una plaza episcopal que finalmente tampoco entró en la órbita cristiana. Conquistada y repoblada Simancas por Alfonso III, en 899, según testimonio de Sampiro, con su hijo García se documenta por vez primera, en 913, el que ya era, o pretendía ser, obispo de Segovia, de nombre Frunimio, quien se nos muestra asimismo junto al rey Ordoño II en 917, sin mencionar de momento su sede, que ya descubre en 927 junto a Alfonso IV, episcopus Secouiensis sedis, aunque su residencia se encontrara de hecho en el monasterio de Santa María de Wamba, próximo a Simancas, según un testimonio del año 938, que viene a ser ratificado por una escritura original del año 948, donde en efecto se le llama episcopus Banbense ${ }^{84}$.

Durante su pontificado, y bajo el gobierno de Ramiro II, la frontera leonesa se había prolongado acentuadamente, y cristianas eran en 939

\footnotetext{
${ }^{81}$ Es sabido que el general inauguró la larga serie de sus campañas con la dirigida contra al-Hamma, que tradicionalmente ha venido identificándose con Los Baños de Ledesma, repoblada por Ramiro II en 939-940, después de la victoria de Simancas, juntamente con Ledesma y Salamanca, según la Chronica Sampiri (ed. PÉREZ DE URBEL, Sampiro, p. 327). Sin embargo, creemos más probable que se trate de Baños de Montemayor, siguiendo a A. CAÑADA JUSTE, "Nuevas propuestas para la identificación de topónimos e itinerarios en las campañas de Almanzor", Anaquel de estudios árabes, 4, 1993, pp. 26-27. Alba de Tormes fue asaltada por Almanzor en 986 (al-'Udrî, p. 63).

${ }^{82}$ También con buen criterio, el citado Cañada Juste (Nuevas propuestas para la identificación de topónimos e itinerarios en las campañas de Almanzor, p. 28), prefiere identificar la Almunia atacada en 980 con esta Armuña (cercana a Coca y Cuéllar), frente a Armuña de Tajuña o Almunia de doña Godina.

${ }^{83}$ Según Ibn Hayyân, el califa "desvió el ejército hacia Riaza, sin dejar fortaleza por destruir, ni alquería por devastar, ni recurso por agotar" (al-Muqtabis $V$, p. 331).

${ }^{84}$ Ed. FLORIANO LLORENTE, Colección diplomática de San Vicente de Oviedo, Oviedo 1968, doc. 11, pp. 43-45. En 938, en el códice canónico de San Juan de la Peña, hoy perdido, al decir de Gómez-Moreno (Iglesias mozárabes, Madrid 1919, pp. 195-196 y nota 3): "Conpletusque in monasterio Ubambe a Nunno diacono licet indigno sub regimine Frunimii episcopi". En 927: "Frunimius episcopus Secouiensis sedis" (ed. SÁEZ, Colección catedral de León, I, doc. 75, 124-129). La confusión entre entre nuestro Frunimio y su homónimo legionense no es posible, ambos apareen en 917: "Frunimius, nutu Dei episcopus... ytem Frunimius, Dei gratia episcopus" (ed. ID., ibid., doc. 43, pp. 70-73); y volverán a coincidir en 928 : "Frunimius, misericordia Dei aepiscopus... Frunimius item, Dei gratia aepiscopus" (ed. ID., ibid., I, doc. 76, pp. 129-131). "Fronismus preceptum dei episcopus" en una carta del año 913 (ed. L. SERRANO, Fuentes para la historia de Castilla: III, Becerro Gótico de Cardeña, Valladolid, p. 327), que no debe ser el leonés, por entonces desterrado en Galicia, según creemos, por el rey García (vid. M. CARRIEDO TEJEDO, "Tres obispos de León -Frunimio, Cixila y Oveco- y el tránsito de la monarquía asturiana a la leonesa", Studium Legionense, 34, 1993, pp. 299316). La Chronica Sampiri registra la repoblación de Simancas: "Sub era DCCCCXXXVII, vrbes desertas ab antiquitus, populares iussit. Hec sunt Çemora, Septimancas et Donnas uel omnes Campis Gotorum" (Ed. PÉREZ DE URBEL, Sampiro, p. 305).
} 
las plazas de Portillo, Mojados, Alcazarén, Olmedo, Íscar y Coca ${ }^{85}$, según Ibn Hayyân, aunque los fuertes baluartes musulmanes de Madrid, Talamanca y Guadalajara hubieron de trastocar el proyecto de los leoneses de ganar Segovia. Muerto Frunimio de Wamba poco después de 948, su sucesor, Ilderedo, fue trasladado por Ramiro II a la cercana ciudad de Simancas en 950. Y aunque Ilderedo es mencionado en los diplomas como obispo de esta ciudad en 963, no por ello ha renunciado al título de la muy cercana Segovia, que él mismo utiliza en un diploma original del año $960^{86}$.

Después de Ilderedo, su sucesor Teodisclo aún aparece en cartas de los años 967 y 969, y ya no tuvo sucesor, pues pocos años después de su muerte, Ramiro III decide suprimir al fin el obispado de Simancas en 974 , lo que era tanto como renunciar a la conquista de Segovia ${ }^{87}$. Y así es como Almanzor dirige ya en 977 la segunda de sus cincuenta y seis campañas contra la estratégica plaza de Cuéllar, en 977, a la que siguió tres años después la de Armuña, y en 983 otra contra la mismísima Simancas, que vino a dar la puntilla definitiva a las aspiraciones sobre Segovia en el siglo $\mathrm{X}^{88}$.

\section{7.- MENCIONES TERRITORIALES ANACRÓNICAS, POR AHMAD AR-RÂZî.}

Ya se ha dicho arriba, al hablar de la Crónica del Moro Rasis, cómo el historiador cordobés se propuso contar sobre las plazas que los musulmanes tenían en su poder, no de las ya perdidas por ellos a manos de los cristianos, ni de las que se encontraban yermas como consecuencia de las campañas de depredación empredidas por Alfonso I de Asturias (739-757): Fasta qui vos avemos ya contado de las villas de España. E non vos las conte todas, mas de las falle en escrito que escriuio Rrasy, que munchas ay otras e muy nobles, mas el non conto de las que los mo-

\footnotetext{
${ }^{85}$ Las plazas del Duero medio las trae Ibn Hayyân (al-Muqtabis $V$, pp. 325 y 339) y Ruiz Asencio (La provincia de Valladolid, pp. 19-23) amplía la lista con otras localidades en el Duero, que también trae a cuento el historiador cordobés, con problemática grafía.

86"Ilderedus Segouiense sedis episcopus" (ed. SÁEZ, Colección catedral de León, II, doc. 333, p. 114). En 963: "Ilderedus episcopus de Septemancas" (ed. MÍNGUEZ, Colección de Sahagún, I, doc. 215, pp. 261262). "Alderedus de Septimanca" en el concilio de León del año 950 (vid. CARRIEDO TEJEDO, "El concilio de León del año 950, presidido por Ramiro II", Tierras de León, 93-94, 1994, pp. 2-30).

${ }^{87}$ Teodisclo aparece, por ejemplo, en una carta de 967 (ed. SÁEZ, Colección catedral de León, II, doc. 403, pp. 188-189); y su último diploma conocido es del año 969 (ed. MÍNGUEZ, Colección de Sahagún, I, doc.253, 298-299). Sobre la supresión del obispado de Simancas, rigurosamente histórico, vid. SÁNCHEZALBORNOZ, "El obispado de Simancas", Miscelánea de Estudios Históricos, León 1970, pp. 392-393).

${ }^{88}$ Al-'Udrî, 57-58: "Hizo Muhammad ibn Abî 'Âmir la campaña de Cuéllar. Fue una aceifa de una penetración". Dikr bilâd al-Andalus, p. 231: "la décima, la de Almunia... la decimoctava, la de Simancas, que conquistó por la fuerza el mismo día que acampó ante ella".
} 
ros avian ya perdidas nin otras muchas que fincaron yermas quando las cristianos fugieron a las Esturias e a Castilla Vieja ${ }^{89}$.

Sin embargo, Manzano Moreno ya puso de manifiesto en su día ${ }^{90}$ cómo Ahmad ar-Râzî incluyó, entre las plazas musulmanas descritas, nada menos que a la lejana ciudad de Narbona, perdida por los musulmanes a mediados del siglo VIII, lo que atribuye el autor al hecho de que el gran historiador cordobés se hubiese servido para trazar su obra de diversas fuentes latinas. Pero además, entre las ciudades mencionadas por el citado autor hay otras tres muy principales que, desde luego, tampoco parecen encontrarse entre las pertenecientes al califato a mediados del siglo X, cuando Ahmad escribe: Coimbra (cristiana), Egitania y Tarragona (en "tierra de nadie"):

1) En cuanto a Tarragona, de las palabras mismas del historiador cordobés se desprende su estado de semirruina durante el siglo X y desde los días del conquistador Tariq: Es çibdat muy vieja e poblada de los antiguos... fue de los logares mas antiguos que fallan fundamientos muy viejos e muy maravillosos, e a y cosas que se non desfazen por ningun tienpo, maguer todas las destruyo Taris, fijo de Mazayr, quando entro en Espana, e el mato las gentes e destruyo las obras, mas non pudo todas, tanto las fizieron firmes; aunque el mismo historiador nos presenta aprovechable su término: fermoso e muy rregantio e conplido de munchos frutos $^{91}$. Palabras que contrastan con las que dedica a Medinaceli, de la que sí nos dice Ahmad ar-Râzî que fue reconstruida y aprovechada por los musulmanes: ay munchas senales antiguas que non se pueden desfazer... es una de las cibdades que Taris, el fijo de Nazayr destruyo; e despues a tienpo poblaronla los moros e moraron en ella ${ }^{92}$.

Ni siquiera contó Tarragona con gobernador militar, según se desprende de al-Muqtabis $\mathbf{V}$, y su estado de postración se deduce además de las continuas alusiones que hace Ibn Hayyân a la extrema Tortosa... extremo del país musulmán... extremo de al-Andalus ${ }^{93}$; de Ibn Hawqal: Tortosa... bordea al país de los francos ${ }^{94}$; y del propio Ahmad arRâzî: Tortosa... es çerca de los de Francia ${ }^{95}$. Hasta el punto que el abad

\footnotetext{
${ }^{89}$ Crónica del Moro Rasis, p. 110.

${ }^{90}$ E. MANZANO MORENO, La frontera de al-Andalus en época de los Omeyas, Madrid 1991, p. 74 (= MANZANO, La frontera de al-Andalus).

${ }^{91}$ Crónica del Moro Rasis, pp. 40-42.

${ }^{92}$ Ibid., p. 59.

${ }^{93}$ IBN HAYYÂN, al-Muqtabis $V$, pp. 148, 211, 352, 363.

${ }^{94}$ IBN HAWQAL, p. 62.

${ }^{95}$ Crónica del Moro Rasis, p. 39.
} 
Cesáreo de Monserrat (o más bien Borrell de Barcelona) vio las condiciones adecuadas para disminuir la influencia del metropolita de Narbona sobre los obispados de Gerona, Urgel, Vic y Barcelona, solicitando y obteniendo de una asamblea de obispos (reunidos en Santiago de Compostela, en 956), el título de metropolitano de la olvidada Tarragona, otrora capital de no pocas sedes episcopales, muchas de las seguían todavía en poder de los musulmanes: Fui ad domum sancti Iacobi, et petivi benedictionem de provincia Tarragona, vel suis munificentiis, hoc est, Barquinona, Egara, Jerunda, Ympurias, Ausona, Urgello, Hilerta, Hycto, Tortosa, Cesaraugusta, Oscha, Pamplona, Aucha, Calahorra, Tirasona. Et fiunt XVI civitates sub metropolitana tarraconensi ${ }^{96}$. Una creciente influencia del conde de Barcelona en esta histórica y fronteriza Tarragona que, visto lo expuesto, puede venir a verse avalada por la noticia de Ibn Jaldûn (que sigue a Ibn Hayyân) al constatar la llegada de un embajador ante Córdoba hacia 950, enviado por el conde Borrell, príncipe de Barcelona y Tarragona ${ }^{97}$. Aunque dicho testimonio no parece tan determinante como para excluir que, muy posiblemente, Tarragona todavía estuviese inserta a mediados del siglo X en la "tierra de nadie" triangulada por los términos de Barcelona (cristiana), Lérida y Tortosa (musulmanas).

2) Por lo que respecta a Egitania (es muy antigua çibdat, e yaze sobre el rrio de Tajo, e es vn lugar muy fuerte e muy bueno de pan, e es de viñas e de caça e de pescado; e es tierra muy deleytosa) ${ }^{98}$, ya nos hemos referido antes a ella al hablar de la "tierra de nadie", en la que se encontraba asimismo su paralela (en tantos sentidos) ciudad de Coria. Dos plazas que fueron atacadas y asoladas por Alfonso III; que tuvieron obispos residentes en la corte ovetense ("in partibus infidelium"); y de las cuales no nos han llegado noticias durante todo el siglo X, pues ni fueron nombrados nuevos prelados en dichas sedes; ni se mencionan designados gobernadores califales por an-Nâsir; ni Almanzor se vio nunca en la necesidad de

\footnotetext{
${ }^{96}$ Ed. ES, XIX, pp. 370-373; vid. CARRIEDO TEJEDO, "El concilio de Santiago del año 956, presidido por Sancho I", Compostellanum, XXXIX (3-4), 1994, pp. 291-311. El abad Cesáreo de Monserrat coincide puntualmente con la lista que trae la Chronica Albeldensia, 154: "Quinta prouintia Tarraconensis: Terracona metropoli, Barcinona, Egara, Gerunda, Inpurias, Ausona, Urigello, Ylerda, Hictoria, Dertosa, Cesaragusta, Osca, Pampilona, Aucca, Calagurre, Tirassona".

${ }^{97}$ Cit. MANZANO, La frontera de al-Andalus, p. 85, quien añade: "Esta incorporación probablemente supuso el final del largo declive de una ciudad que, a mitad de camino entre los dos principales centros urbanos de la región -Barcelona y Tortosa-, se había configurado como típico territorio fronterizo, en la que la ausencia de asentamientos estables lo convierten en una «tierra de nadie», donde se libran escaramuzas y combates aislados".

${ }^{98}$ Crónica del Moro Rasis, p. 86.
} 
neutralizar una posible posición de los critianos en ella ${ }^{99}$. Y no es improbable que en ambos obispados visigodos de la Lusitania central se produjera el mismo proceso de progresivo deterioro urbano hasta su definitivo abandono.

3) $\mathrm{Y}$ en cuanto a Coimbra, es todavía más desconcertante, si cabe, su inclusión en la Crónica del Moro Rasis, como si en verdad Ahmad arRâzî la hubiera contado con toda la consciencia entre las plazas de los musulmanes: La çibdat de Coynbra es muy fuerte e es castillo muy alto e muy noble; yaze sobre el rrio que ha nombre Mudel, e este rrio nasçe en la çierra del Estrella e yaze sobre muchos castillos e muy buenos e muy fuertes que obedeçen a Coynbra... es muy buena e muy abondada de todos los bienes; e ha vna bega sementera rribera del rrio que non ha tan buena en toda España que rregantia non sea... e la çibdat de Coynbra es muy viçiosa e de muchas huertas e de muchos frutales de muchas guisas, e los mas son oliuares e dan el mejor azeyte que ha en el mundo ${ }^{100}$; pues, en efecto, hoy es sabido que fue ganada en 878 por el conde Hermenegildo Gutiérrez, bajo el reinado de Alfonso III, según el Chronicón Laurbanense: Era DCCCCXVI prendita est Coninbriga ab Hermegildo comi$t e^{101}$; noticia avalada, según se ha dicho arriba, por la Chronica Albeldensia $^{102}$, por la Crónica de Sampiro ${ }^{103}$, y, lo que es más importante, por el propio Ahmad o su hijo 'Îsà, pues uno de los dos "ar-Râzî" define a Galicia como extremo del reino leonés que llega a Coimbra, cerca de tierra musulmana, de la que el enemigo se había apoderado hacía po$c o^{104}$; y es 'Îsà el que expresamente presenta al infante Ramiro Ordóñez, luego Ramiro II, viviendo en la tierra suroccidental del reino: hasta el limite de Coimbra ${ }^{105}$; cuyos habitantes se sumaron a las tropas leonesas que derrotaron a las cordobesas en Simancas, según Ibn Hayyân: Habian recibido refuerzos... de los infieles de Coimbra, pues con ellos había toda clase de cristianos ${ }^{106}$.

\footnotetext{
${ }^{99}$ Vid. notas 77 a 80, ambas inclusive. El citado Manzano (La frontera de al-Andalus, pp. 188-189), constata el inicial asentamiento de bereberes en Coria, luego emigrados a Mérida, como consecuencia de las acciones del rey Magno, y concluye: "La consecuencia de todo ello parece haber sido la pérdida de Coria en favor del reino asturleonés, dado que esta ciudad ya no aparece mencionada en las fuentes durante la época califal".

${ }^{100}$ Crónica del Moro Rasis, p. 85.

${ }^{101}$ Vid. SÁNCHEZ-ALBORNOZ, "Primeras empresas alfonsíes", Orígenes III, p. 620.

${ }^{102}$ Chronica Albeldensia, pp. 250-251.

${ }^{103}$ SAMPIRO, Crónica, p. XVVIII.

${ }^{104}$ IBN HAYYÂN, al-Muqtabis $V$, p. 103.

${ }^{105}$ ID., ibid., p. 259 . Un cronista leonés presenta también al futuro Ramiro II residiendo en la cercana ciudad de Viseo, al acontecer la abdicación de su hermano Alfonso IV el Monje en 931 ("Alfonso, hijo de Ordoño... envió emisarios por su hermano Ramiro a tierras de Viseo, diciendo cómo quería renunciar al reino y cederlo a su hermano"; SAMPIRO, Crónica, p. CII).

${ }^{106}$ IBN HAYYÂN, al-Muqtabis $V$, p. 330.
} 
Otras tres plazas hay (Nájera, Viguera, Arnedo) pertenecientes al término (musulmán) de Tudela, que Ahmad ar-Râzî sitúa (¿sólo convencionalmente?) en el ámbito córdobés. Las tres ya habían sido tomadas por los cristianos en el año 924, de lo que parece hacerse eco el mismo Ahmad, al menos en lo que respecta a Arnedo: Tudela ha muchas villas e muchos castillos e muy fuertes, de los quales es el vno Arruyt. E quando Espana de moros era, era Arruyt su escudo contra los christianos. Arruyt es muy antygua villa. E ha vna villa que ha nonbre Calahorra; e otra que ha nonbre Najara; e otra que ha nonbre Locayra, que es castillo muy fuerte $^{107}$; pues hoy es bien conocido, gracias a Sampiro: $1^{\circ}$ ) Que en 923 Ordoño II tomó la susodicha Nájera, que de antiguo se llamaba Tricio $^{108} ; 2^{\circ}$ ) Que Viguera también fue conquistada en esta misma campaña,lo que motivó una respuesta del califa en 924, movido por el suceso de los Banu Lubb y los Banu Di n-Nun en la fortaleza de Viguera, en el límite de la Marca Superior ${ }^{109} ; 3^{\circ}$ ) Que Arnedo ya era cristiana en 920, pues según 'Arîb b. Sa'îd, durante la campaña de Muez, an-Nâsir pasó el Ebro, saliéndole al encuentro de su vanguardia con sus mesnadas el maldito Sancho, desde Arnedo ${ }^{110}$.

Si Ahmad ar-Râzî incluyó en su descripción la plaza de Arnedo, que "había sido" escudo contra los cristianos, quiere decir que el autor (muerto en 955 y que según se ha dicho llegó a historiar en su Mujtasar al menos hasta el año 941), escribió tal vez su Descripción General de al-Andalus con posterioridad al año 920, y no es imposible que mencionara el castillo de Arnedo (con los de Nájera y Viguera) por lo reciente de su pérdida, como hizo en otra de sus obras al hablar de Coimbra, de la que el enemigo se había apoderado de ella hacía poco ${ }^{111}$.

\section{8.- LAS OSCILACIONES FRONTERIZAS: LOS CASOS DE CALAHO- RRA Y GORMAZ.}

Dejando a un lado las plazas fronterizas ganadas originariamente por los cristianos mediante repoblación oficial en "tierra de nadie" (casos de Coimbra, Viseo, Lamego, Oporto, Salamanca, Ledesma, Zamora, Toro, Dueñas, Simancas, Roa, Haza, Osma, Coruña del Conde, San Esteban

\footnotetext{
${ }^{107}$ Crónica del Moro Rasis, p. 53.

${ }^{108}$ SAMPIRO, Crónica, p. CI.

${ }^{109}$ IBN HAYYÂN, al-Muqtabis $V$, p. 147.

${ }^{110}$ ID., ibid., p. 131.

${ }^{111}$ ID., ibid., p. 103.
} 
de Gormaz y Sepúlveda, por ejemplo) ${ }^{112}$, lo cierto es que con anterioridad al comienzo de las campañas amiríes (en 977), han llegado muy pocos testimonios que nos permitan documentar conquistas sucesivamente alternas por parte de leoneses a los cordobeses, y viceversa, en los territorios limítrofes, lo que tal vez nos venga a confirmar una vez más el importante papel jugado por el "vacío jurídico" estratégico existente entre las dos líneas fronterizas efectivas de ambos reinos ${ }^{113}$, y ello teniendo en cuenta que a medida que se estrecha hacia levante la franja de la "tierra de nadie" es cuando se pueden constatar tales casos de conquistas alternativas:

CALAHORRA.- Sabemos (siguiendo siempre aquí a Ibn Hayyân) que fue ganada por los cristianos con anterioridad a 914 (en este año conquistaron los de la Marca Superior la fortaleza de Calahorra, que estaba en manos de los infieles ${ }^{114}$ ). Sin embargo, y ya en 920, Sancho Garcés I nuevamente la había convertido en base contra los musulmanes ${ }^{115}$. En 924, el rey pamplonés se vio en la necesidad de evacuarla, debido a la presión del califa: En el país infiel de Pamplona... su primer alto fue en la fortaleza de Calahorra, que su jefe Sancho, a quien Dios maldiga, había evacuado... la fortaleza de Calahorra, que estaba abandonada, ordenando su destrucción y arrasamiento ${ }^{116}$. Y en 934 nos consta ya en poder de los cordobeses, con motivo de la entrevista entre la reina Toda de Pamplona y el propio califa: Toda hija de Aznar, que se acogía a su obediencia... llegando prontamente a sus reales en Calahorra ${ }^{117}$. Y así permaneció luego, musulmana, hasta el año 1045.

GORMAZ.- Repoblada muy probablemente en 912, al mismo tiempo que San Esteban, lo cierto es que en el año 934, durante la campaña contra Osma, an-Nâsir mató al señor de la fortaleza de Gormaz, notable entre sus condes, e hizo alto en la plaza, sita a 10 millas de Ayllón, también cristiana $^{118}$. Luego, en 939, la tenían nuevamente los cristianos, pues el califa se proponía avanzar por el Duero a San Esteban y Gormaz, al

\footnotetext{
${ }^{112}$ Basta repasar la Chronica Albeldensia, la Crónica de Alfonso III, los Anales Castellanos Primeros y la Chronica Sampiri.

${ }^{113}$ Vid. SÁNCHEZ-ALBORNOZ, Despoblación y repoblación del valle del Duero, Buenos Aires 1966 , donde con paciencia y rigor se recogen muchos testimonios que avalan suficientemente (hasta el punto de que lo que hoy habría que demostrar lo contrario) la existencia de una "tierra de nadie" depoblada entre musulmanes y cristianos.

${ }^{114}$ IBN HAYYÂN, al-Muqtabis $V$, p. 85.

${ }^{115}$ ID., ibid., p. 130.

${ }^{116}$ ID., ibid., pp. 148 y 151 .

${ }^{117}$ ID., ibid., pp. $251-252$.

${ }^{118}$ ID., ibid., p. 256.
} 
escasear las provisiones... pero la gente de Guadalajara y sus fortalezas se le quejaron de lo que sufrían a causa de los infieles del valle de Riaza y sus castillos $^{119}$. En 942, su conde, enviado por Ramiro II junto con otros cristianos contra Tudela, fue muerto en una batalla contra las tropas musulmanas (allí murieron Abû l-Mundir, conde de Gormaz, el conde Gómez de Cerezo y el sobrino de González, entre los notables cristia$n o s^{120}$ ). Pero en 975 , los musulmanes ya la habían reconquistado, pues 'Îsà b. Ahmad ar-Râzî nos informa cómo se habían congregado junto a Ramiro III (para asediarla), Sancho Garcés II de Pamplona, García Fernández de Castilla, Fernando Ansúrez de Peñafiel y los Banu Gómez de Saldaña (se habian concertado para asediar el castillo... a incitación del rey de todos ellos Ramiro ibn Sancho ibn Ramiro que... vino al castillo desde su capital, la ciudad de León, ;Dios la extermine!, en medio de estruendoso ejército y acompañado de su tía paterna la infiel Elvira, la misma que no habia cesado de ratificar la tregua y de solicitar su vigencia. $\left.^{121}\right)$.

\section{9.- LA FRONTERA EN LOS TRATADOS DE PAZ.}

Por desgracia, no es mucho lo que hoy sabemos sobre las embajadas y las condiciones estipuladas en los tratados de paz firmados entre Córdoba y León ${ }^{122}$. Del primero de los tratados conocidos en el siglo X, firmado en 935, se nos dice que el califa an-Nâsir hizo la paz con Ramiro hijo de Ordoño... tras pedirsela... con repetidos mensajeros que se la solicitaban. Para ratificar sus cláusulas, envió a Yahyà b. Ishâq a la capital de Ramiro, hasta concluirla, una vez puesta a punto, con los hombres de confianza de Ramiro, en el estrado de an-Nâsir, y ratificarla con testigos en presencia de los notables del reino, el martes, a mediados de rabî' II de este año (24 abril), fecha señalada en Córdoba por la magnificencia y esplendor de que se hizo gala. An-Nâsir se había decidido a esta paz... para cortar la ayuda que daba su adversario Ramiro II al rebelde señor de Zaragoza, Muhammad b. Hâšsim ${ }^{123}$.

Nada sabemos, pues, sobre los condicionantes territoriales que contenía la tregua. Luego, extraña la celeridad tan acentuada que demostró el rey leonés para repoblar la tierra del Tormes, inmediatamente después de su sonada victoria estival en la batalla de Simancas, en la primera

\footnotetext{
${ }^{119}$ ID., ibid., p. 331.

${ }^{120} \mathrm{ID} .$, ibid., p. 364.

${ }^{121}$ ID., Anales palatinos, p. 276.

${ }^{122}$ Vid. CARRIEDO TEJEDO, "Embajadas califales en León", Archivos Leoneses, 75, 1984.

${ }^{123}$ IBN HAYYÂN, al-Muqtabis $V$, pp. 273-274.
} 
quincena de agosto de $939^{124}$, pues según Sampiro, al segundo mes, dispuso que fuese una expedición a la ribera del Tormes, y allí pobló ciudades desiertas $^{125}$. Y no es imposible que esta celeridad tenga que ver con los cálculos del frío rey leonés, quien tal vez buscó fijar estos hechos consumados en las conversaciones de paz que inició con el califa pocos meses después, durante el primer semestre de 940: En este año fueron frecuentes las cartas de Ramiro hijo de Ordoño, rey de los leoneses, pidiendo la paz y tregua ${ }^{126}$.

El califa mandó por fin salir a su embajador hacia León para concluir las cláusulas de la paz, en junio de 940, regresando a Córdoba 47 días después, en agosto, junto con los representantes leoneses, los cuales dejaron tal vez constancia clara de la intención que tenía Ramiro de plasmar la reciente y apresurada repoblación salmantina en un acuerdo que, desde luego, no fue del agrado de an-Nâsir, quien, informado de los deseos de los mensajeros de Ramiro acerca de la paz, no aceptó algunas excepciones que hacian a las condiciones e hizo volver a los mensajeros del tirano para dar cumplimiento a su fórmula sobre el particular y concluir la paz ${ }^{127}$. Y a pesar de que llegaron a irritar a 'Abdarrahmân III los ambages del rey Ramiro ${ }^{128}$, y de que los embajadores leoneses frecuentaron Córdoba para el asunto de la paz ${ }^{129}$, ésta terminó llegando en du 1qa'da de 329 (28 julio - 26 agosto 941), concluyéndola an-Nâsir en su capital con las cláusulas que al califa plugo imponerse, del mismo modo que antes había hecho el tirano Ramiro en su propia capital, previa la delimitación negociada antes en la ciudad leonesa por el judío Hasdây.

Así pues, que hubo acuerdos territoriales parece no sólo lógico deducirlo, sino necesario el plantearlo, visto lo expuesto, pues además se añade expresamente que con la firma se puso fin a la guerra entre las dos comunidades desde Santarén a Huesca, al asociar el rey católico al rey de Pamploma, al conde de Castilla, y a otros condes fronterizos ${ }^{130}$, que en

\footnotetext{
${ }^{124}$ Anales Castellanos Primeros: "En la era 977 (= año 939), a saber, en la segunda feria (lunes) a la hora tercia mostró Dios un signo en el cielo y el sol se convirtió en tinieblas durante casi una hora en todo el mundo. Después, a los dieciocho días, el séptimo de los idus de agosto ( 6 agosto) en el día que los cristianos celebran a los santos Justo y Pastor, tercera feria (martes), vinieron los cordobeses a Simancas" (ed. GÓMEZMORENO, vid. SÁNCHEZ-ALBORNOZ, La España musulmana, Madrid 1973, 337). Vid. etiam supra (textos de la nota 39) lo que traen la Crónica de Sampiro, p. CIV, e IBN HAYYÂN, al-Muqtabis V, pp. 325326.

${ }^{125}$ SAMPIRO, Crónica, p. CIV.

${ }^{126}$ IBN HAYYÂN, al-Muqtabis $V$, p. 344.

${ }^{127}$ ID., ibid., pp. 344-345.

${ }^{128}$ ID., ibid., p. 350.

${ }^{129}$ ID., ibid., p. 348.

${ }^{130}$ ID., ibid., p. 351.
} 
consecuencia hubieron de asumir también unas cláusulas cuyo contenido hoy se nos escapa.

Luego, nada sabemos de los acuerdos suscritos entre Ramiro y an-Nâsir en 942, cuando el califa ordenó viajar hasta León a un nuevo embajador en union de Ya'far b. Yahyà b. mdm. para entrevistarse con el bárbaro Ramiro según sus instrucciones. Ambos salieron... a fines de rabî' II (21 enero)" ${ }^{131}$. Y menos aún sabemos, o podemos deducir, de los acuerdos establecidos en el tratado de paz gestionado en 955 y firmado en 956, en el que Ordoño III, según Ibn Jaldún, mandó pedir la inclusión de Fernán González, conde de Castilla... y an-Nâsir accedió a los solicitado $^{132}$. Una paz a la que siguió dos años después, en 958, la humillación de la reina Toda de Pamplona ante el mismo califa, posternándose ante él para pedirle el otorgamiento de la paz en favor de ella y de su nieto Sancho I de León ${ }^{133}$, todo ello frente a las pretensiones de su rival, Ordoño IV, otro monarca títere, como el anterior, que a su vez viajó a Córdoba en 962 para pedir también el favor del nuevo califa, al-Hakam II, en el transcurso de una audiencia en la que el soberano cordobés declaró tener las mejores intenciones en favor del leonés: Recibirás de nosotros tantos beneficios como recibió tu adversario (Sancho) de nuestro padre... te conduciremos a tu país... y te enviaremos un tratado en el que fijaremos los límites de tu reino y del de tu primo. Además, impediremos a este último que te inquiete en el territorio que te tendrá que ceder ${ }^{134}$. Todo lo cual quedó finalmente sin cumplir, pues, finalmente, el nuevo califa decidió mantenerse en la línea de conducta de su padre an-Nâsir para con Sancho y accedió a reconocerlo bajo ciertas condiciones, entre las cuales estaba la de demoler las fortalezas y las torres que se hallaban cerca de las fronteras de los musulmanes ${ }^{135}$.

\footnotetext{
${ }^{131}$ ID., ibid., p. 357.

${ }^{132}$ IBN JALDÛN, Historia de los árabes de España; trad. O. A. MACHADO MOURET, Cuadernos de Historia de España, 45-46, 1967, p. 392.

${ }^{133}$ ID., ibid., pp. 392-393.

${ }^{134}$ AL-MAQQARI, Nafh al-tib; según versión inglesa de Gayangos y francesa de Dozy, trad. castellana de SÁNCHEZ-ALBORNOZ, La España Musulmana, Madrid 1973, p. 374.

${ }^{135}$ IBN JALDÛN, Historia de los árabes de España; trad. MACHADO MOURET, Cuadernos de Historia de España. 47-48, 1968, p. 357. Podría decirse que todavía lo ignoramos todo, prácticamente, sobre las relaciones diplomáticas entrambos reinos. Sabemos de la estancia en León, durante 941, junto al judío Hasdây, de tres obispos mozárabes: El metropolitano 'Abbâs b. al-Mundir, obispo de Sevilla; Ya'qûb b. Mahrán, obispo de Pechina; y 'Abdalmalik b. Hassán, obispo de Elvira (IBN HAYYÁN, al-Muqtabis V, pp. 350-351). Pero tal vez seguirá siendo una incógnita por mucho tiempo el porqué de la presencia en el reino cristiano de algunos otros curiosos personajes andaluces: En 931 un "Iulianus Dei gratia episcopus de Vivester" (ed. M. LUCAS ÁlVAREZ, El Tumbo de San Julián de Samos. Estudio introductorio. Edición diplomática. Apéndices e índices, Santiago de Compostela 1986, = Samos, doc. 34, pp. 123-125), a quien creemos posible identificar con el titular de Bobastro, refugiado tal vez en León después de los desgraciados acontecimientos vividos en su sede. En 932 aparece un "Iulius episcopus de Badaliaucu" (ed.ID., La documentación del Tumbo A de la
} 
A esas alturas ya había comenzado, de hecho, el principio del fin de la importante línea defensiva que (entre mesetas) trabajosamente habían contribuido a afianzar durante toda una centuria (850-951) los más importantes monarcas de la dinastía neogótica: Ordoño I, Alfonso III, Ordoño II y Ramiro II. Luego siguieron 25 años (951-976) con una situación fronteriza adormecida y más insegura que nunca, como consecuencia de la aguda debilidad militar leonesa (nunca compensada por la creciente iniciativa de los condes castellanos: Fernán González y su hijo García Fernández); y después, otro cuarto de siglo de incesantes acometidas de Almanzor (976-1002), que harán retroceder por fin la frontera cristiana hasta curso del río Duero (que había tenido un siglo antes).

Habrá que esperar otra media centuria para que la frontera vuelva a alcanzar (con Fernando I, 1038-1065, y ahora ya de forma irreversible) el límite conseguido por Ramiro II a mediados del siglo X, paralelo a la divisoria peninsular imaginada por Ibn Hayyân entre las dos lejanas plazas musulmanas: de Santarén a Huesca.

catedral de Santiago de Compostela, León 1997, = Santiago, doc. 39, pp. 131-13). En 937 un "Julianus hispalensis episcopus" (ed. etiam QUINTANA PRIETO, El obispado de Astorga en los siglos IX y X, pp. 331334). En 952 un "Martinus abba Cordouensis", acompañado por un "Mudarrafe filius Abumar", esto es, Mutarrif b. Abû 'Umar (ed. ID., Temas bercianos, II, Ponferrada 1967, pp. 385-386). Y es muy conocida otra escritura de Sahagún, fechada el 5 de febrero de 1003, donde se constata que fue expedida "in presentia qui ibi fuit zacbascorta Eben Bacri quando uenit de Cordoba pro pace confirmare ad Romanos in Domnos Sanctos" (AHN, BGS, ff. 144v-145r; ed. M. HERRERO, Colección diplomática del monasterio de Sahagún -857-1230:III -1073-1109-, León 1988, doc. 380, pp. 22-23). 
